Woods Hole Oceanographic Institution

Technical Report

November 1994

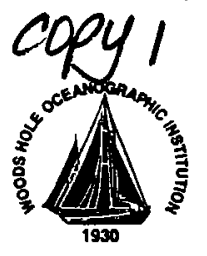

\title{
Design and Validation of a Modified Eppley PSP Pyranometer
}

by

Richard E. Payne

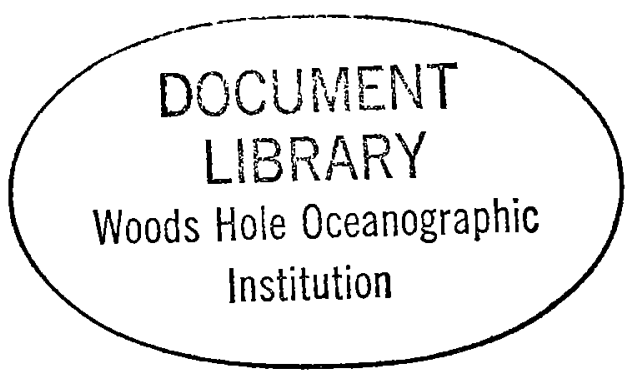




\title{
WHOI-94-30 \\ UOP Report 94-5
}

\section{Design and Validation of a Modified Eppley PSP \\ Pyranometer}

\author{
by \\ Richard E. Payne \\ Woods Hole, Massachusetts 02543 \\ November 1994

\section{Technical Report}

Woods Hole Oceanographic Institution

Funding was provided by the National Science Foundation under Grant No. OCE-91-15000.

\begin{abstract}
Reproduction in whole or in part is permitted for any purpose of the United States Government. This report should be cited as Woods Hole Oceanog. Inst. Tech. Rept.,
\end{abstract} WHOI-94-30.

Approved for public release; distribution unlimited.

\section{Approved for Distribution:}

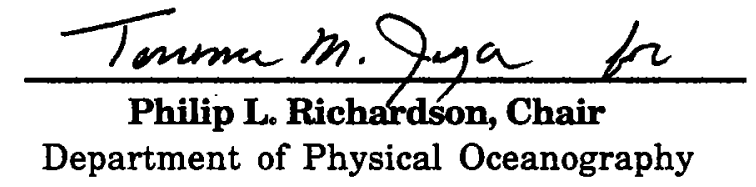





\begin{abstract}
A modified version of the Eppley PSP pyranometer has been designed for use on ships and moored buoys. Seventeen have been built by the Eppley Laboratory for the Upper Ocean Processes Group and deployed on buoys in the deep ocean. Six others have been incorporated into IMET systems mounted on U.S. research ships. A comparison study between four Improved METeorology (IMET) PSPs and one standard PSP shows that the two are completely equivalent in performance. The IMET PSP is more corrosion resistant, compact, robust, and is easier to mate to electronics modules. It is available from the Eppley Laboratory for about the same price as the standard PSP.
\end{abstract}




\section{Table of Contents}

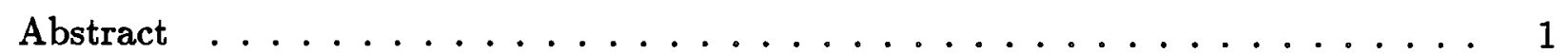

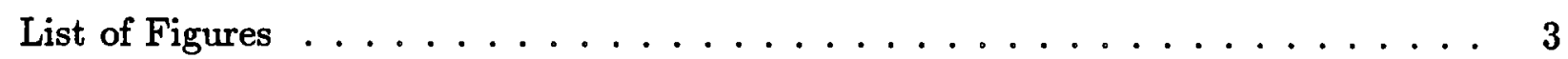

List of Tables ............................ . . 4

1. Introduction ...................... 5

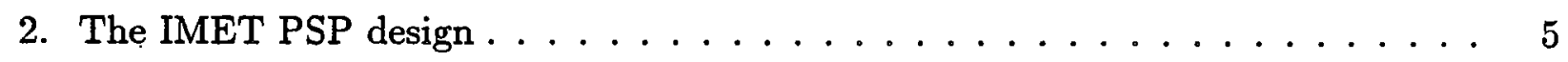

3. Pyranometer Comparison ........................ 6

4. Comparison with other results $\ldots \ldots \ldots \ldots$

5. Field Experience . . . . . . . . . . . . . . . . . . 11

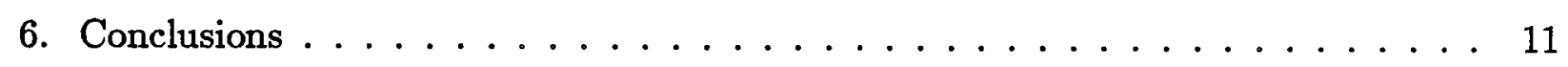

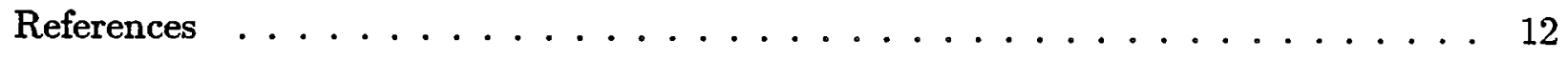

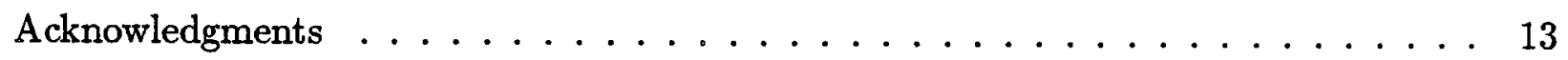




\section{List of Figures}

1. Photograph of standard Eppley PSP . . . . . . . . . . . . . 14

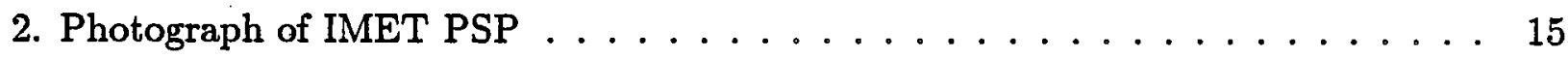

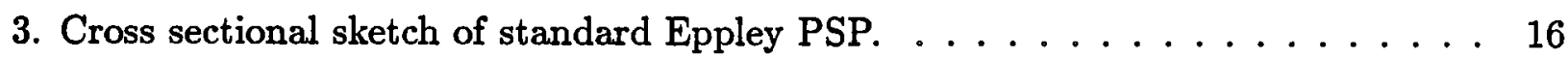

4. Cross sectional sketch of IMET PSP. . . . . . . . . . . . . . 17

5. Radiometer test bench on Clark roof $\ldots \ldots \ldots \ldots \ldots$

6. Total irradiance and atmospheric transmittance . . . . . . . . . . . . 19

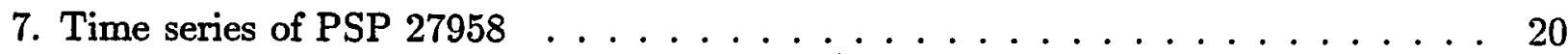

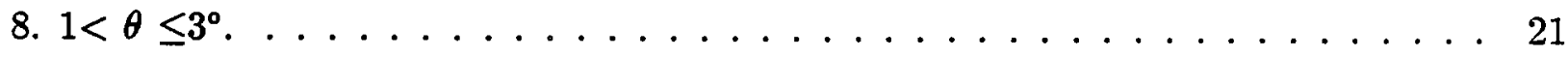

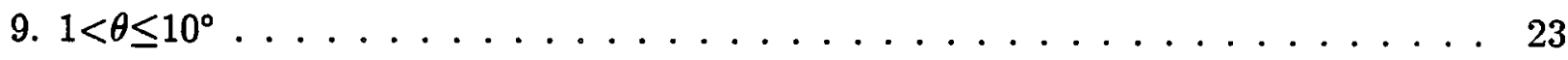

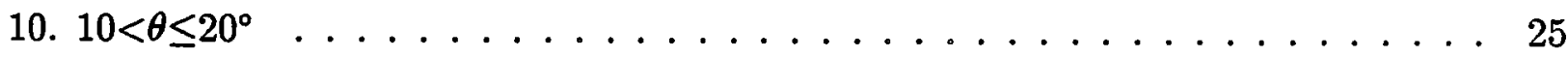

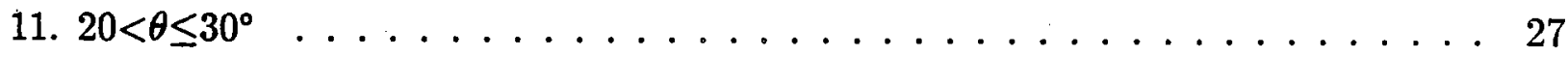

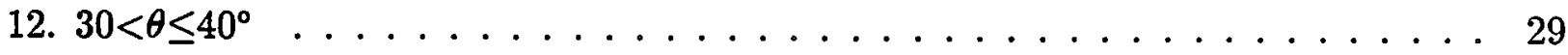

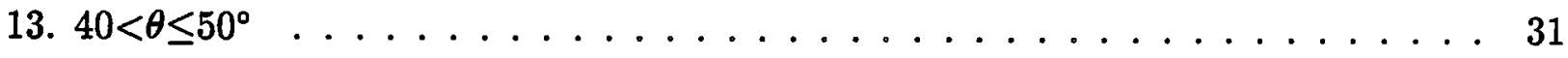

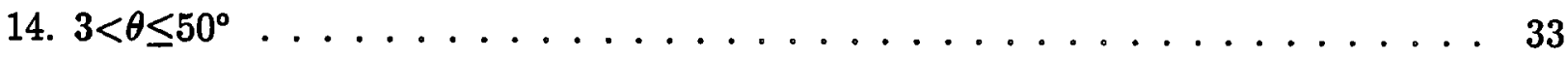

15. Slopes of linear fits of 4 PSPs vs PSP $27958 \ldots \ldots \ldots \ldots \ldots$

16. Temperature dependence of calibration coefficient $\ldots \ldots \ldots \ldots$ 


\section{List of Tables}

1. Pyranometer Calibrations .................... 7

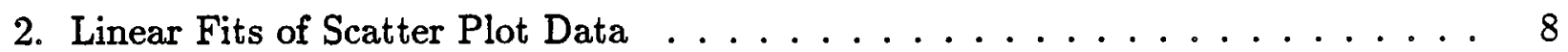




\section{Introduction}

The IMET (for Improved METeorological sensing and recording) system was developed by the Upper Ocean Processes Group (UOP) at the Woods Hole Oceanographic Institution (WHOI) for measuring the surface meteorological parameters required for the computation of heat and momentum fluxes across the sea surface from buoys (Hosom et $a l ., 1994)$. The objective for developing the IMET system was to attempt to measure the various meteorological parameters to sufficient accuracy to permit computation of heat fluxes to an accuracy of $10 \mathrm{Wm}^{-2}$. As part of the development project, sensors for all the necessary parameters were tested to enable us to specify a suitable set of sensors for the IMET system.

Short-wave solar radiation is the most significant source of heat for the ocean and plays an important part in the physics of the upper ocean. In our original tests, we looked at three radiation sensors, the PSP and 8-48 from The Eppley Laboratory and the Hollis MR-5. The first two are thermopile sensors and the third a silicon photovoltaic sensor. We determined that the Eppley PSP returns the most accurate observations and, subsequently, specified it for the IMET system (Crescenti et al., 1989).

\section{The IMET PSP design}

The Eppley PSP (Precision Spectral Pyranometer) detects solar radiation in the wavelength band 285-2800 millimicrons, the limits of transparency of the WG295 glass used in the two hemispheres. The flux of energy parallel to the sensor's axis is proportional to the temperature difference, as measured by a thermopile, between a blackened surface under the glass hemispheres and the pyranometer body temperature. A passive circuit incorporates a thermistor embedded in the body to compensate for most of the temperature coefficient of the thermopile. Significant to its performance are good heat flow through the upper part of its body and an absence of anomalous warming of the body. In its standard PSP, Eppley mounts the components in a cast bronze body, topped by a stainless steel ring holding the outer glass hemisphere. See Figures 1 and 2 for photographs and Figure 3 for a cross sectional sketch of the PSP. The stainless steel top is shielded from solar radiation by a slightly conical disk of thin aluminum shown in Figure 1. The disk is painted bright white and the body a cream color for reflection of solar radiation.

Several features of the standard PSP make it less than ideal for long buoy deployments: 
1. The combination of aluminum, bronze, and stainless steel in contact with each other leads to galvanic corrosion.

2. The shield is fragile and easily damaged during buoy deployments and recoveries.

3. The sensor is designed for mounting on a flat surface, often not easily obtained on a buoy.

4. A cable is required between the pyranometer and supporting electronics which can be a source of failures, especially at its ends.

I modified the Eppley PSP design to develop a sensor better adapted to UOP group use. The IMET PSP (see Figures 2 and 4) is made entirely of aluminum, anodized and painted with a bright white, durable paint, on all exposed surfaces. It mates to the IMET electronics tube via a Delrin collar to which it is attached by internal screws. Since 1990, seventeen IMET PSPs have been built for us by the Eppley Laboratory.

After discussion of the PSP design with Eppley experts, it was apparent that the critical heat flow in the body was in part $\mathrm{C}$ on Figures 3 and 4. Modifying parts $\mathrm{A}$ and $\mathrm{B}$ would be unlikely to affect performance. In place of the stainless steel ring and aluminum shield, I chose to substitute white painted aluminum with a sloping surface. The result is a compact sensor, not easily fouled and readily mated to its accompanying electronics.

Being able to mount the amplifier and the rest of the module electronics in close proximity to the sensor has had unanticipated advantages. The short leads reduce effects of radiation from the two or more Argos transmitters which are typically mounted on our buoys and eliminate one external cable with its possibility of failure at each end.

\section{Pyranometer Comparison}

To test for effects of the design modification on the PSP performance, I compared three IMET PSPs, one of them our working standard, with a standard Eppley PSP and an Eppley 8-48 pyranometer. Calibration dates and constants for all the sensors are listed in Table 1. The IMET serial number 27958 is our working standard. It was calibrated by Eppley when new and less than a year later by the Solar Energy Research Institute (SERI, now the National Renewable Energy Laboratory, NERL). NERL, and SERI before it, uses the outdoor calibration method in which the output of the sensor being calibrated is compared to the sum of the direct and indirect components of the downward flux. The direct component is measured with a pyrheliometer and the indirect by a calibrated PSP with the direct solar radiation shaded by a disk. Measurements are made on clear days, 
when the direct component is most of the downward flux. Since the pyrheliometer makes a primary measurement, this is largely a primary calibration. Eppley calibrates by comparing a pyranometer with their working standard under an illuminated hemisphere (Drummond and Greer, 1966). Their working standard is calibrated by the outdoor calibration method. For PSP 27958, the two calibrations agreed within $0.7 \%$.

\section{Table 1. Pyranometer Calibrations}

\begin{tabular}{llll}
$\begin{array}{l}\text { Serial } \\
\text { No. }\end{array}$ & $\begin{array}{l}\text { Date } \\
\text { Cal. Constant }\end{array}$ & $\begin{array}{l}\text { Date } \\
\text { Cal. Constant }\end{array}$ & $\begin{array}{l}\text { Date } \\
\text { Cal. Constant }\end{array}$ \\
\hline PSP 27294 & $10 / 88$ & & \\
& $8.16 \mathrm{v} \mathrm{W}^{-1} \mathrm{~m}^{2}$ & & \\
PSP 27706 & $7 / 89$ & $1 / 90$ & $6 / 92$ \\
& 8.48 & 8.40 & $8.60 \mathrm{v} \mathrm{W}^{-1} \mathrm{~m}^{2}$ \\
PSP 27985 & $2 / 90$ & $10 / 91$ & \\
& $9.21($ Eppley) & $9.27(\mathrm{SERI}) \mathrm{v} \mathrm{W}^{-1} \mathrm{~m}^{2}$ & \\
PSP 28189 & $8 / 90$ & $1 / 94$ & \\
& 7.91 & $7.79 \mathrm{v} \mathrm{W}^{-1} \mathrm{~m}^{2}$ & \\
$8-489891$ & $3 / 81$ & $10 / 81$ & $10 / 86$ \\
& 10.76 & 10.73 & $10.77 \mathrm{v} \mathrm{W}^{-1} \mathrm{~m}^{2}$
\end{tabular}

The sensors were mounted on our rooftop radiometer test bench as shown in Figure 5. The bench is on the roof of the Clark building on a ridge overlooking Nantucket Sound and about $1 / 4$ mile from the water. The bench has an excellent exposure to the sky. A few small tree tops, about $50 \mathrm{~m}$ away, rise no more than $2^{\circ}$ above the horizontal plane of the sensors and subtend a very small solid angle.

Since the IMET PSPs do not have bubble levels, I used a different, and more precise, method of leveling all the pyranometers. All three models (PSPs and 8-48) have a surface outside the outer hemisphere base that I assume is coplanar with the sensing surface. An aluminum tube was machined whose inside diameter is a little larger than the outer hemisphere. The tube's length is a little greater than the height of the PSP hemisphere and its ends were carefully lapped to make them highly parallel. To level a pyranometer, the tube is set on the pyranometer and a Smartlevel (a digital level) is set on the top of the tube. All pyranometers have three leveling screws and they are levelled by watching the Smartlevel output in the three planes while adjusting the screws. The Smartlevel has a precision of $0.1^{\circ}$ and is run through its calibration procedure before each leveling exercise. The pyranometer leveling is accurate to within $0.2^{\circ}$. 
Outputs of four of the pyranometers were connected directly to the input channels of a Campbell Scientific model CR7 data logger. PSP 27706 had an amplifier mounted in it which had an amplification factor of about 100. The CR7 sampled each of the inputs once per second and averaged over 10 minutes before recording them internally. The time constant of the PSP is $1 \mathrm{~s}$ (Eppley literature and Zerlaut and Maybee, 1984) and of the $8-48$ is $5 \mathrm{~s}$ (Eppley literature). Data was uploaded to a PC over a telephone link and the CR7 clock was adjusted 4-5 times per week. This kept the real time clock within $5 \mathrm{~s}$ of UTC.

Figure 6 shows the total irradiance data and the atmospheric transmittance values from all five pyranometers for one completely cloudless day. The atmospheric transmittance is obtained by dividing the individual irradiance values by the computed noatmosphere value with the data logger time corrected to local solar time. The symmetry between the ends of the day show that all five pyranometers were leveled precisely and that the times recorded were correct. No-atmosphere values were computed from algorithms for sun altitude in Doggett et al (1978).

Data were recorded from 2 September to 14 October 1994, a remarkably clear period on Cape Cod. Data from several intervals when the data logger malfunctioned were deleted from the final data set. Figure 7 shows the data from PSP 27958 for all the time periods used. During the processing, the most recent calibration constants for each pyranometer were applied to compute 10 -minute averages in watts $/ \mathrm{m}^{2}$. The final data set was sorted into several files by solar altitude at the middle of the interval: $1<\theta \leq 3,1<\theta \leq 10,10<\theta \leq 20$, $20<\theta \leq 30,30<\theta \leq 40,40<\theta \leq 50,3<\theta \leq 50^{\circ}$. There were no sun altitudes more than $50^{\circ}$, and none less than $1^{\circ}$ were included. Scatter plots of the data for each pyranometer against PSP 27958 for each of the angle intervals and for the whole data set appear in Figures 814. Least squares fits were made corresponding to each of the scatter plots, the results of which are in Table 2. A plot of the slopes vs sun altitude appears in Figure 15.

Table 2. Linear Fits of Scatter Plot Data

\begin{tabular}{rrrrrrrrrr} 
& \multicolumn{4}{c}{ PSP 28189 } & PSP 27294 & PSP 27706 & $8-48$ & 9891 \\
& $\mathrm{~N}$ & $\mathrm{~S}$ & SD & S & SD & S & SD & S & SD \\
$1<\theta \leq 3$ & 55 & 1.040 & 1.3 & 0.886 & 3.5 & 0.895 & 2.7 & 1.017 & 9.3 \\
$1<\theta \leq 10$ & 262 & 1.027 & 2.0 & 0.937 & 4.5 & 0.950 & 3.4 & 1.086 & 10.6 \\
$10<\theta \leq 20$ & 288 & 1.021 & 4.4 & 0.937 & 5.5 & 0.955 & 3.9 & 1.065 & 8.0 \\
$20<\theta \leq 30$ & 316 & 1.014 & 3.1 & 0.944 & 3.9 & 0.965 & 3.5 & 1.041 & 5.7 \\
$30<\theta \leq 40$ & 424 & 1.024 & 4.5 & 0.956 & 5.0 & 0.971 & 5.0 & 1.024 & 5.7 \\
$40<\theta \leq 50$ & 302 & 1.028 & 4.1 & 0.963 & 4.6 & 0.977 & 4.2 & 1.012 & 5.5 \\
$3<\theta \leq 50$ & 1628 & 1.026 & 4.1 & 0.963 & 5.4 & 0.976 & 4.5 & 1.017 & 8.2
\end{tabular}

$\theta=$ sun altitude $\mathrm{N}=$ Number of points $; \mathrm{S}=\mathrm{Slope} ; \mathrm{SD}=$ Standard deviation $\left(\mathrm{Wm}^{-2}\right)$. 
The close agreement between all the PSPs in this study, aside from differences in calibration constants, is apparent in both the plots and the standard deviations in Table 2. The slopes are also plotted for the $10^{\circ}$ ranges in Figure 15. The Model 8-48 pyranometer is an entirely different design from the PSP and less accuracy is claimed for it by Eppley. The decreased accuracy is apparent in the plots and its standard deviations, particularly at low sun elevations.

The linear fits of the whole data set are the most helpful for evaluating the relative calibrations since the slopes evaluate the difference between the calibration of IMET PSP 27958 and the others. There is reason for confidence in the calibration of IMET PSP 27958 since the Eppley and SERI calibrations differed only by $0.7 \%$. The slopes show that PSP 27294, the stock Eppley version, differs from IMET PSP 27958 by $3.7 \%$.

The calibration coefficients of the IMET pyranometers tested differ from that of PSP 27958 by up to $2.4 \%$ as seen in the slopes in Table 2. Of the seventeen IMET PSPs we own, ten have had two calibrations and three have had three. The differences in calibration coefficient from one calibration to the next have a mean of $-0.8 \%$ with a standard deviation of $2.1 \%$. The two extreme values are $-3.8 \%$ and $2.6 \%$. Although Eppley claims consistency of $1 \%$ (John Hickey, personal communication) the calibration differences between the other PSPs and PSP 27958 seem to agree with the accuracy of Eppley calibrations in as implied by the calibration history of 28189 and 27706 .

\section{Comparison with other results}

The apparent calibration coefficient of a pyranometer varies with its temperature, and with the altitude and azimuth of the source relative to the pyranometer. Published documentation of these effects is rare and difficult to obtain. The few existing reports appear in proceedings of meetings, most of them in Europe. One such meeting was a symposium on "Recent Advances in Pyranometry" sponsored by the International Energy Agency and held in Norrkoping, Sweden during January 1984. I will quote results from several papers from this meeting.

\section{Temperature dependence}

Most of the temperature dependence of the thermopile is compensated by a passive circuit incorporating a thermistor mounted in the pyranometer body. The magnitude and temperature dependence of the residual varies from one pyranometer to another. The data supplied by Eppley for each of the tested pyranometers is shown in Figure 16. The worst 
case differences are $-1.2 \%$ for PSP 27958 at $40^{\circ} \mathrm{C}$ and $1.1 \%$ for PSP 27294 at $-20^{\circ} \mathrm{C}$. Liedquist (1984) measured the temperature dependence of five PSPs. His graph shows that all were low at low temperatures and four were high at $35^{\circ} \mathrm{C}$. The worst case ratio at $-25^{\circ} \mathrm{C}$ of measured to room temperature response is 0.98 , or $2 \%$ negative. The worst case at $35^{\circ} \mathrm{C}$ is 1.01 , or $1 \%$ positive. This is larger than the Eppley-supplied numbers. Flowers (1984), however, states that the temperature effect is less than $1 \%$.

\section{Sun altitude and azimuth effects}

An ideal pyranometer would have a response which matches the cosine of the zenith angle (the angle between an incident light beam and the vertical) and which is independent of the azimuth of the source relative to the pyranometer. Liedquist (1984) found that three of his PSPs decreased in response with increasing zenith angle relative to a cosine. He found a range of magnitudes. The worst case was 0.99 at $30^{\circ}, .97$ at $60^{\circ}$, and below .90 at greater than $80^{\circ}$. This appears to be an extreme case. Flowers (1984) found cosine variations of 1-2\%. Nelson and Dutton (1994) also find decreasing response with increasing zenith angle but ignored azimuthal effects.

Liedquist found that sensitivity to azimuth varied up to $8 \%$, with the sign different in opposite $180^{\circ}$ segments. Flowers finds that the azimuth effect is $0-2 \%$.

Solar altitude and azimuth effects are combined in the data from this study. Table 2 shows differences from one $10^{\circ}$ altitude band to another but these represent different azimuth ranges as well. The $40-50^{\circ}$ interval represents a fairly small range in azimuth centered on due south (solar noon). Each of the other intervals represents a sum of an easterly and a westerly azimuth band, becoming progressively more easterly and westerly with decreasing solar altitude.

On a moored buoy, azimuthal effects will be averaged out since the buoy orientation is usually uncorrelated with sun azimuth. At sun elevations much larger than the maximum buoy pitch and roll amplitude, of order $10^{\circ}$ for our $3 \mathrm{~m}$ discus buoys, the effect of non-cosine response evidences itself as the effects of time averaging over pitch and roll (Katsaros and DeVault, 1986; MacWhorter and Weller, 1991). At lower sun elevations, shading is much more severe than the deviation from cosine response of the sensor surface as it rolls away from the sun. 


\section{Comments}

All of the PSPs in this study vary in their apparent calibration coefficients with changes in sun altitude. There is insufficient data to make any statements about azimuthal effects. By the results in Table 2, these combined variations are of order 1-2\%. The fluxes computed with the Eppley calibration coefficients for any single range of conditions differ by up to $6 \%$ from those of PSP 27958. Although Eppley claims consistency of better than $1 \%$, we have seen variations in successive calibrations of a single PSP of up to $4 \%$. The largest difference is for the standard Eppley, PSP 27294. All of the variations seen in this study are similar to those seen by other investigators (Flowers, 1984; Liedquist, 1984; Zerlaut and Maybee, 1984; Nelson and Dutton, 1994) for standard PSPs.

\section{Field Experience}

IMET PSPs were deployed on each of 4 buoys (either $3 \mathrm{~m}$ discus or $2 \mathrm{~m}$ toroid) in the three consecutive, eight-month settings of the Subduction experiment, on the central buoy in the TOGA-COARE experiment, and on several other moorings of 2-5 months duration. One PSP has spent a total of 21 months on a bow meteorological mast on the RV Oceanus in addition to 7.5 months on a Subduction buoy. The sensors have experienced no failures and, except for two which were not anodized before being painted, they have not deteriorated.

\section{Conclusions}

The differences seen between the IMET PSPs and the standard Eppley PSP are similar to those seen by other investigators among standard PSPs. Thus, the IMET PSP seems to be completely equivalent in performance to the standard Eppley PSP. The IMET PSP represents an attractive alternative to the standard PSP from the standpoints of corrosion resistance, compactness, ruggedness, and convenience in mating to electronics modules. The IMET PSP is available from The Eppley Laboratory on special order for approximately the same price as the standard PSP. 


\section{References}

Crescenti, G. H., Richard E. Payne, Robert A. Weller, 1989. Improved Meteorological measurements from buoys and ships (IMET): preliminary comparison of pyranometers. Woods Hole Oceanog. Inst. Tech. Rept., WHOI- 89-47, IMET TR-89-04, 30 pp.

Doggett, L. E., G. H. Kaplan, and P. K. Seidelmann, 1978. Almanac for Computers, Nautical Almanac Office, United States Naval Observatory, Washington, DC, 20390.

Drummond, A. J. and H. W. Greer, 1966. An integrating hemisphere for the calibration of meteorological pyranometers. Solar Energy, 10, 7-11.

Flowers, F., 1984. The intercomparison of pyranometers at horizontal, $45^{\circ}$ tilt, and normal incidence. Proc. Symp. Recent Advances in Pyranometry, January 1984, S.M.H.I. Norrkoping, Sweden, pp 222-249. International Energy Agency.

Hosom, David S., Robert A. Weller, Richard E. Payne, Kenneth E. Prada, 1994. The IMET (Improved METeorology) Ship and Buoy Systems. Journal of Atmospheric and Oceanic Technology, in press.

Katsaros, K. B., and J. E. DeVault, 1986. On irradiance measurement errors at sea due to tilt of pyranometers. Journal of Atmospheric and Oceanic Technology, 3, 740-745.

Liedquist, L., 1984. The intercomparison of pyranometers at horizontal, 45 degrees tilt, and normal incidence. Proc. Symp. Recent Advances in Pyranometry, January 1984, S.M.H.I. Norrkoping, Sweden, pp 65-94. International Energy Agency.

MacWhorter, M. A., and R. A. Weller, 1991. Error in measurement of incoming shortwave radiation made from ships and buoys. Journal of Atmospheric and Oceanic Technology, 8, 108-117.

Nelson, D. W., and E. G. Dutton, 1994. Improved characterization of "Traditional" 2pi steradian broadband solar radiometers. Preprint vol., Eighth Conference on Atmospheric Radiation, 23-28 January 1994, Nashville, TN. Pub. by Amer. Met. Soc., pp 191-193.

Zerlaut, G. A., and G. D. Maybee, 1984. The intercomparison of pyranometers at horizontal, $45^{\circ}$ tilt, and normal incidence. Proc. Symp. Recent Advances in Pyranometry, January 1984, S.M.H.I. Norrkoping, Sweden, pp 194-215. International Energy Agency. 


\section{Acknowledgments}

George Kirk and John Hickey of the Eppley Laboratory, Inc., were quite helpful in an initial conference and several telephone conversations. The development of the IMET system, including the redesign of the PSP sensor, was supported by Grant OCE-87-09614 from the National Science Foundation (NSF) Ocean Science Division as part of the Long Lead Time Development Activity for the World Ocean Circulation Experiment (WOCE). Documentation of the development was supported on NSF Grant 91-15000, also from the NSF Ocean Science Division. 


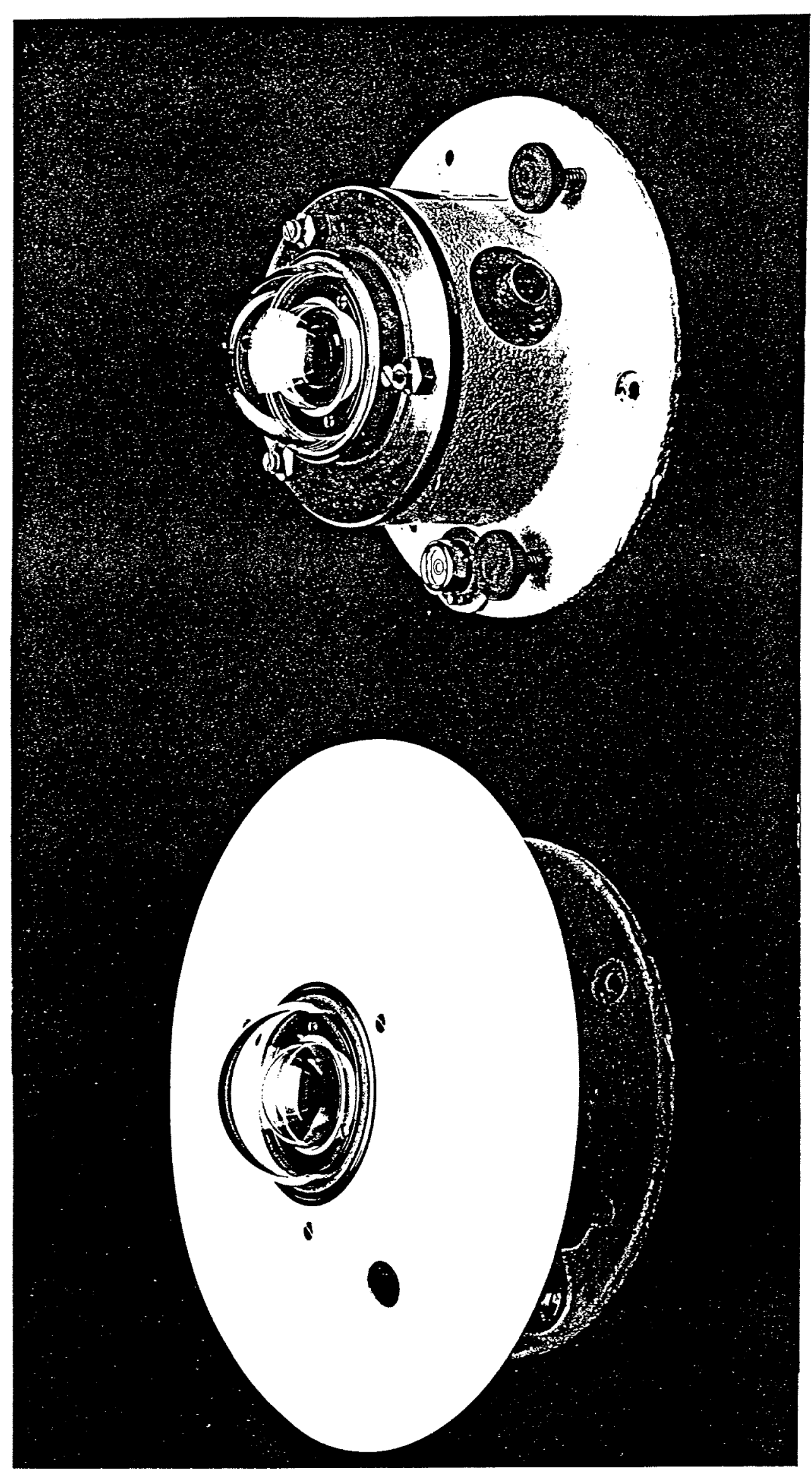

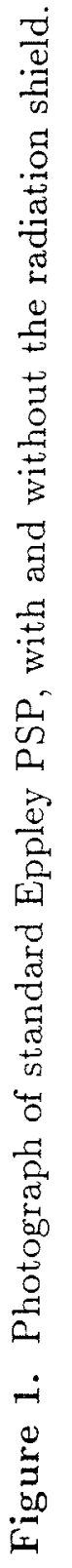




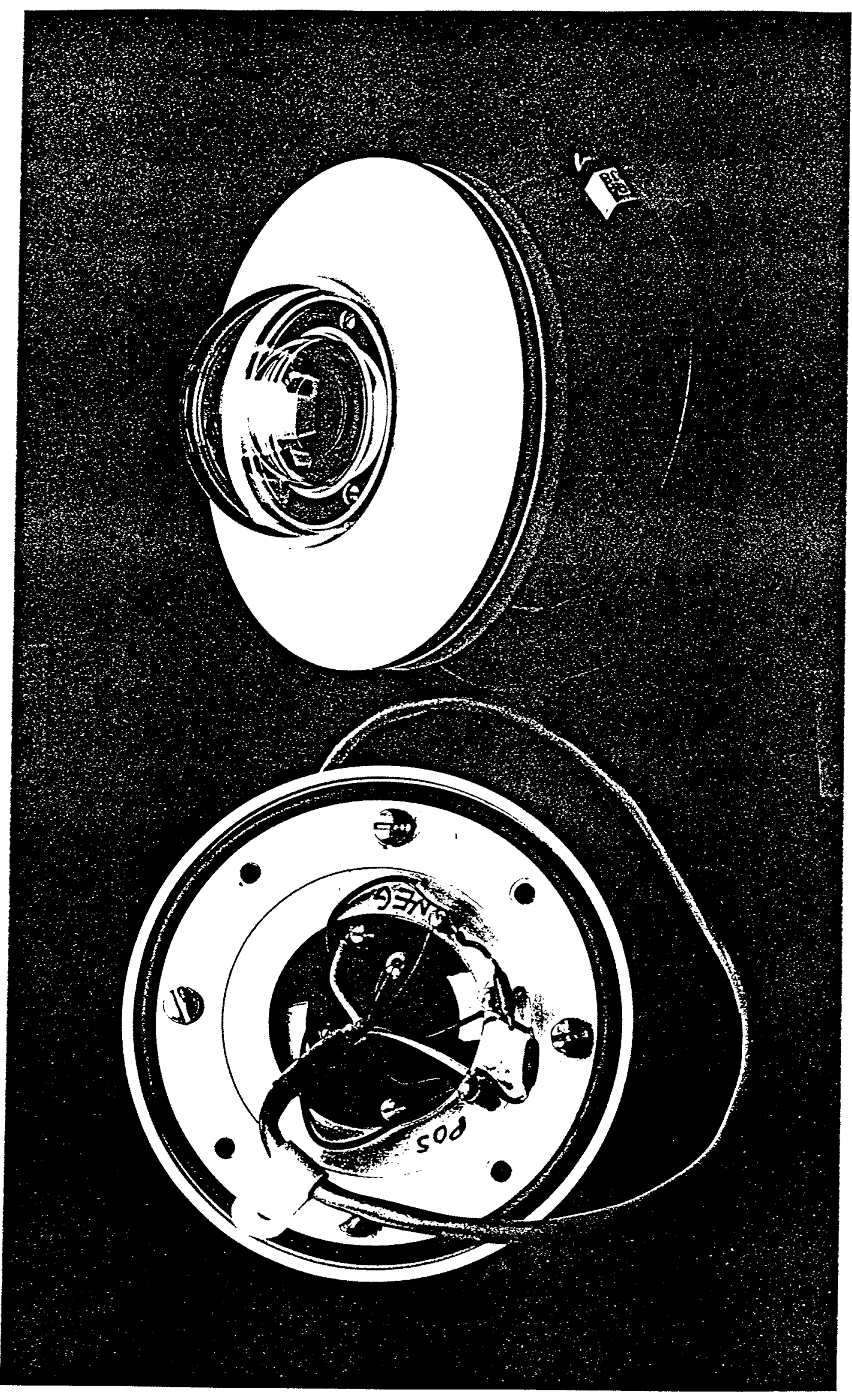

0
0
0
0
0
0
0
0
-1
0
00
0
0
0
-1
0
0
0
0
3
00
0 


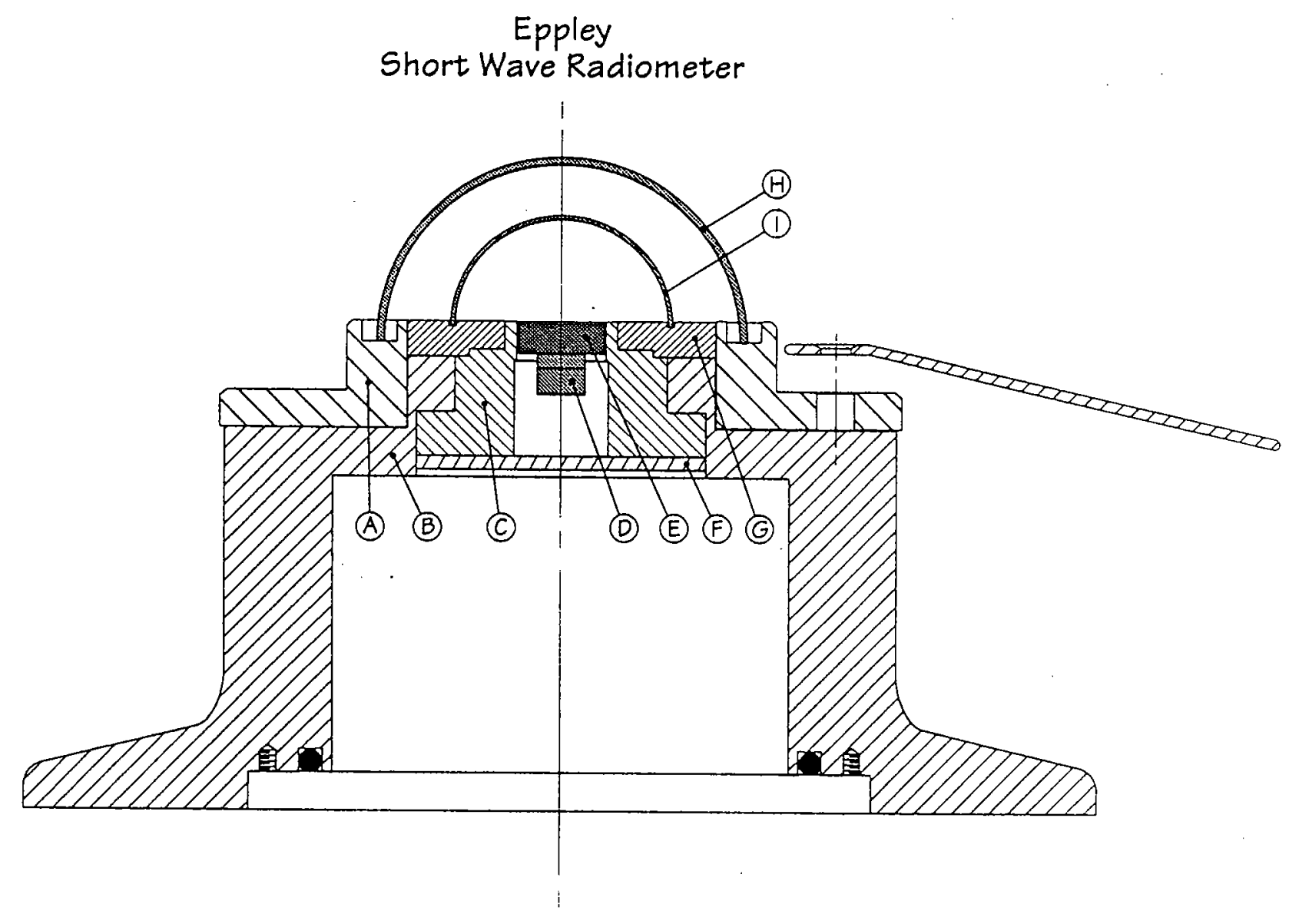

Figure 3. Cross sectional sketch of standard Eppley PSP. Materials: A - Stainless steel; B - Cast bronze; C,D,E,F - shield Aluminum; G - Chrome plated brass; H, I - Schott WG295 glass. 


\section{IMET PSP Short Wave Radiometer}

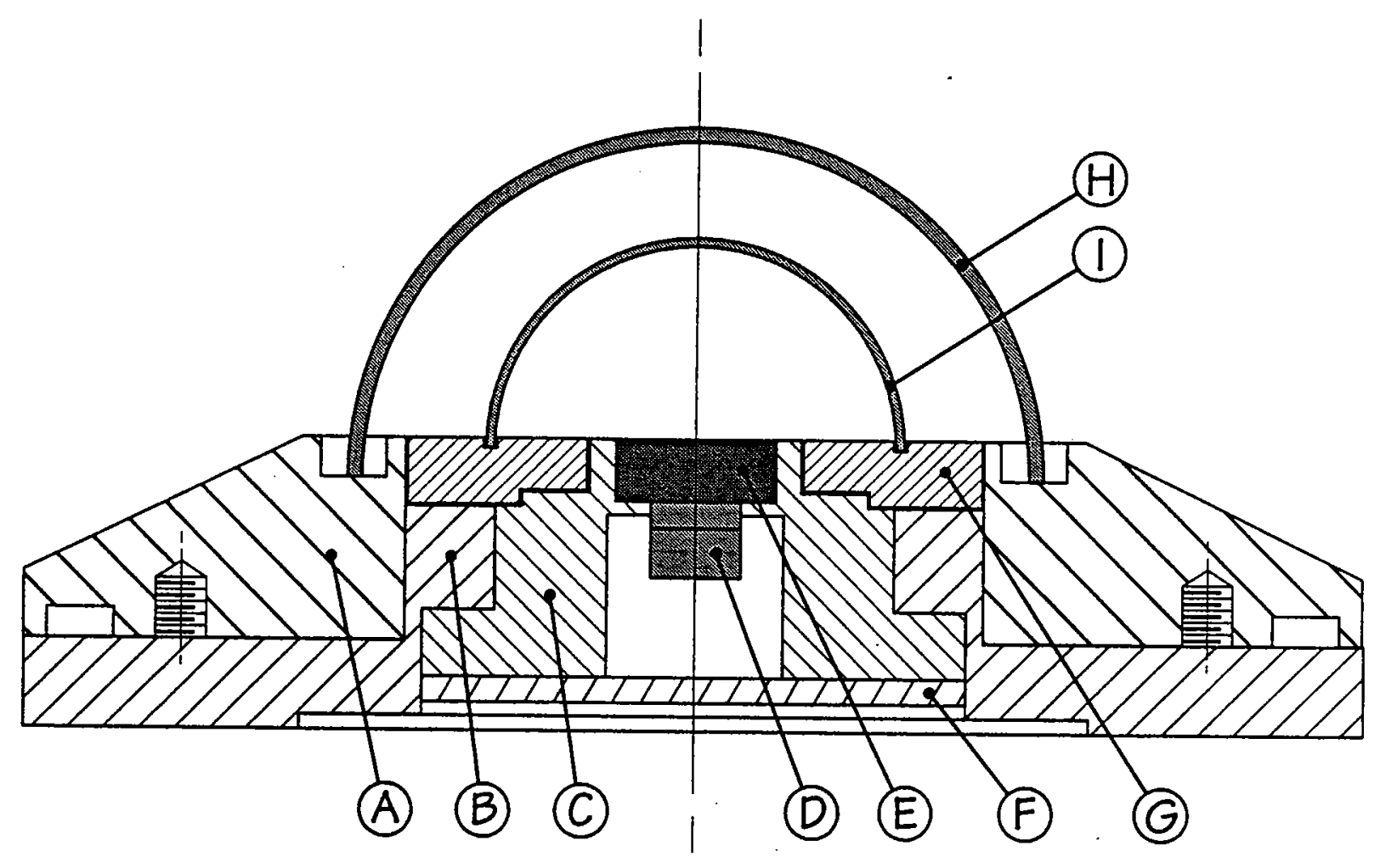

Figure 4. Cross sectional sketch of IMET PSP. Materials: A,B,C,D,E,F-Aluminum; G - Chrome plated brass; H,I, - Schott WG295 glass. 


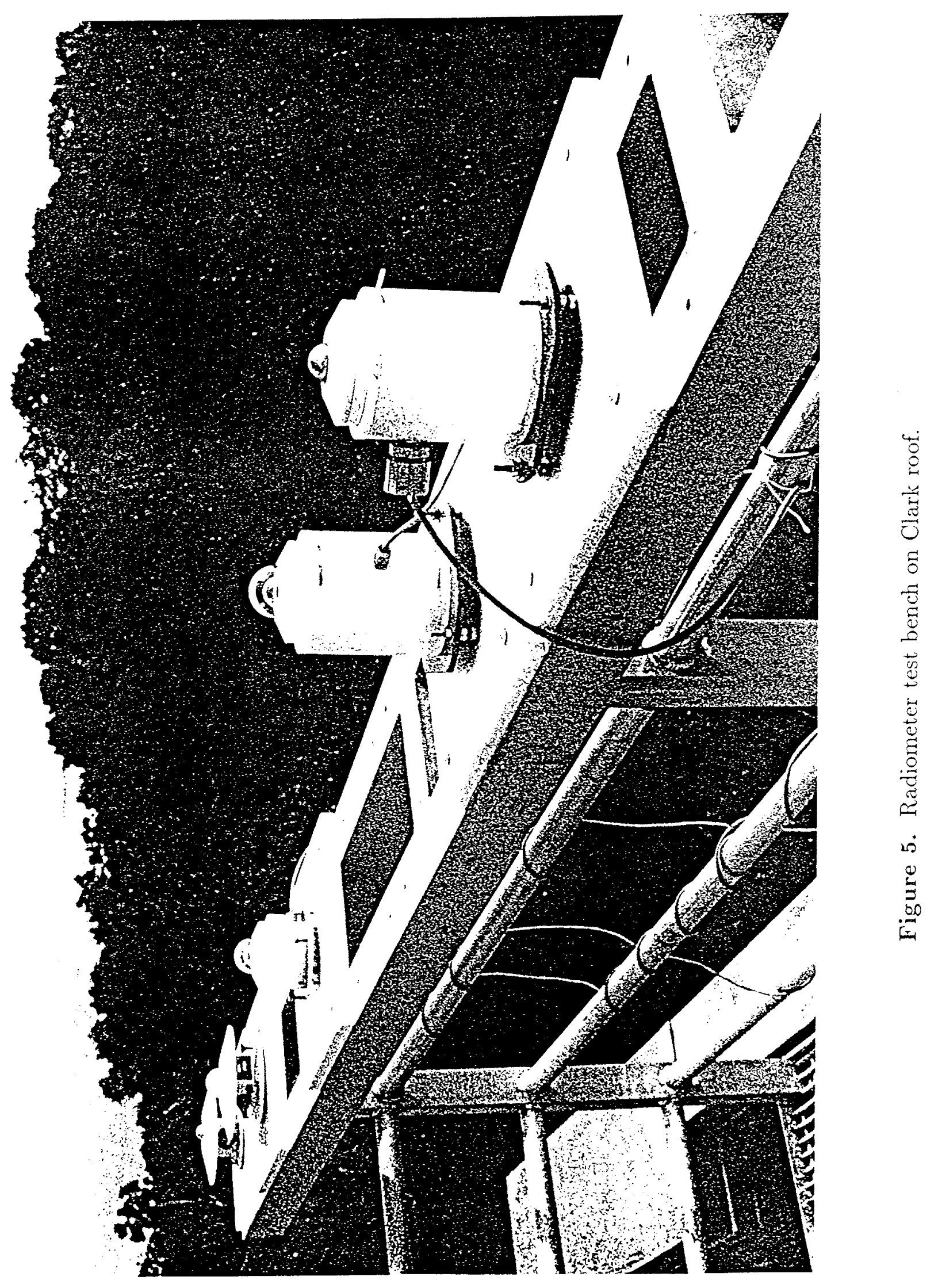




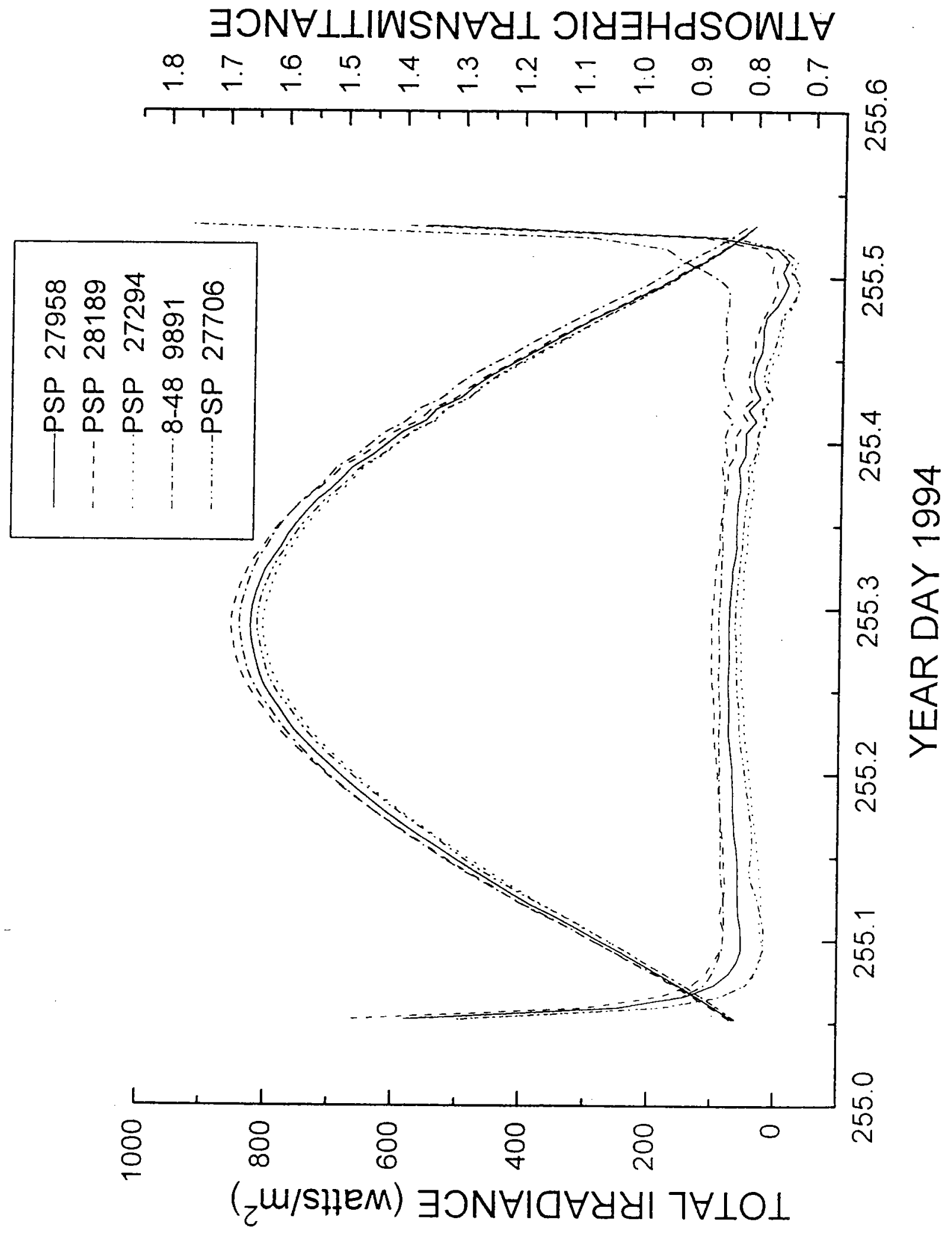

Figure 6. Total irradiance and atmospheric transmittance from September 12 from all five pyranometers. 


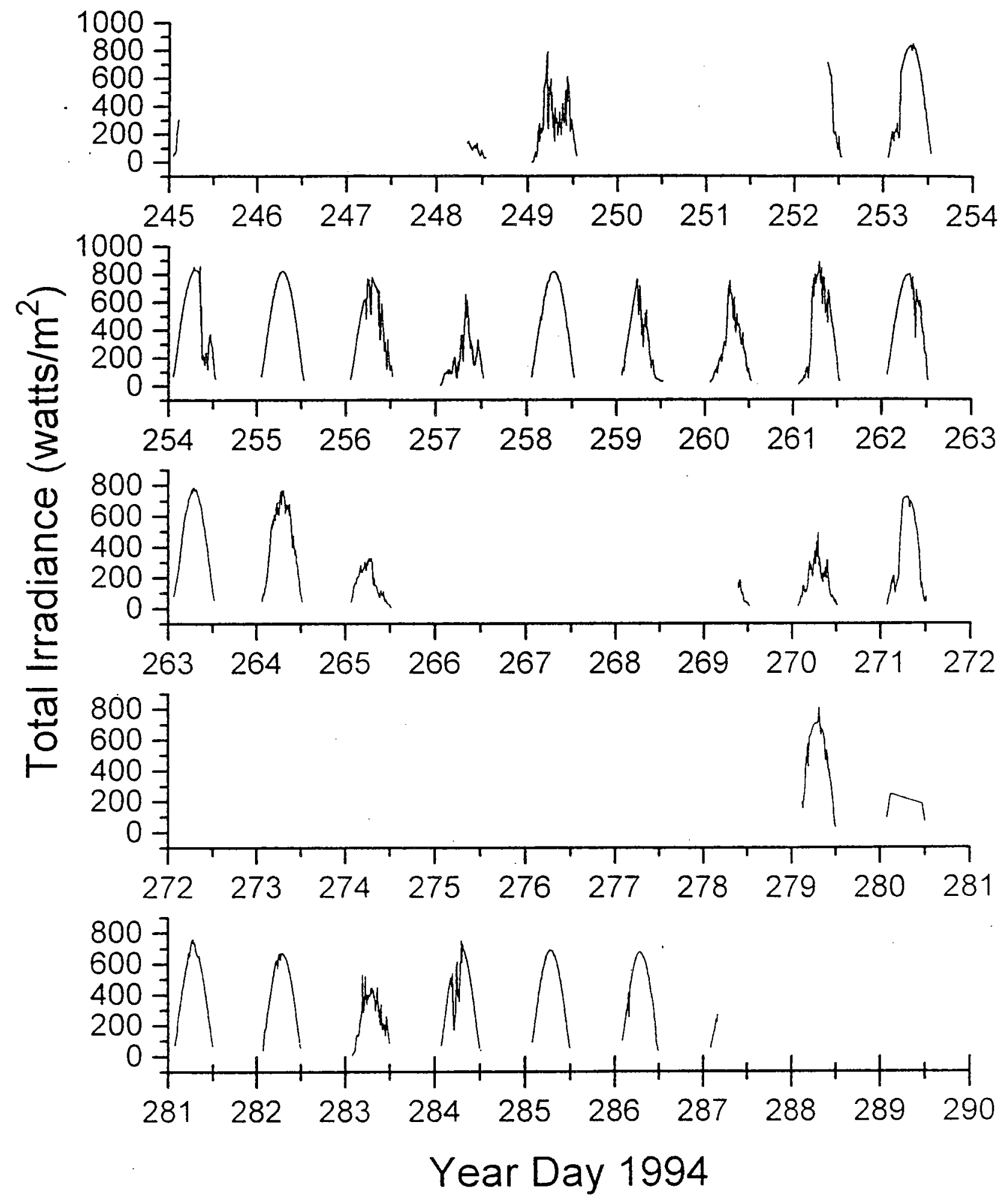

Figure 7. Time series of PSP 27958 irradiance showing data used in comparison analysis. 
$120 \quad 1<$ Sun Altitude $<3$ degrees
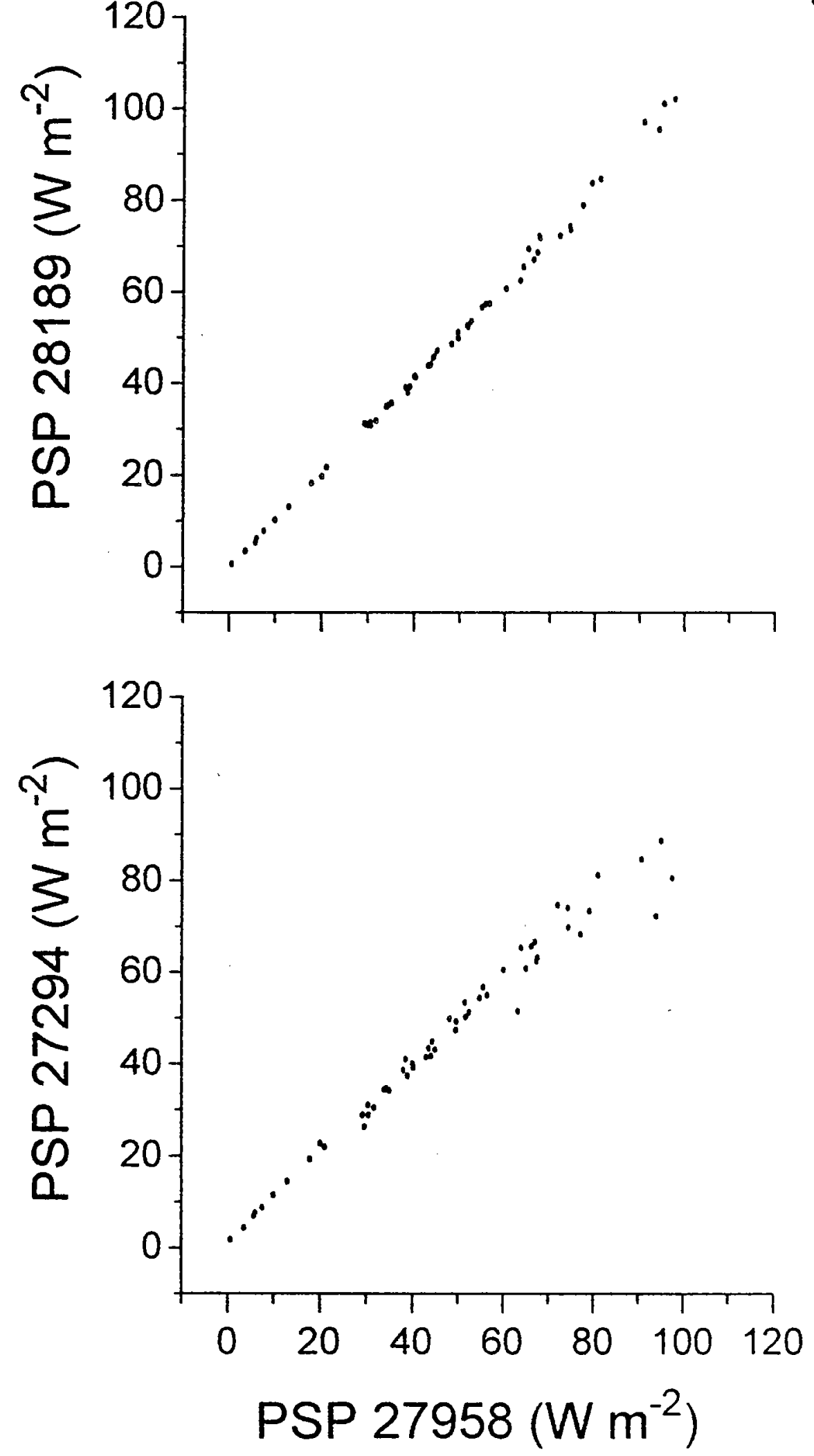

Figure 8a. $\quad 1<\theta \leq 3^{\circ}$. 


\section{$1<$ Sun Altitude $<3$ degrees}
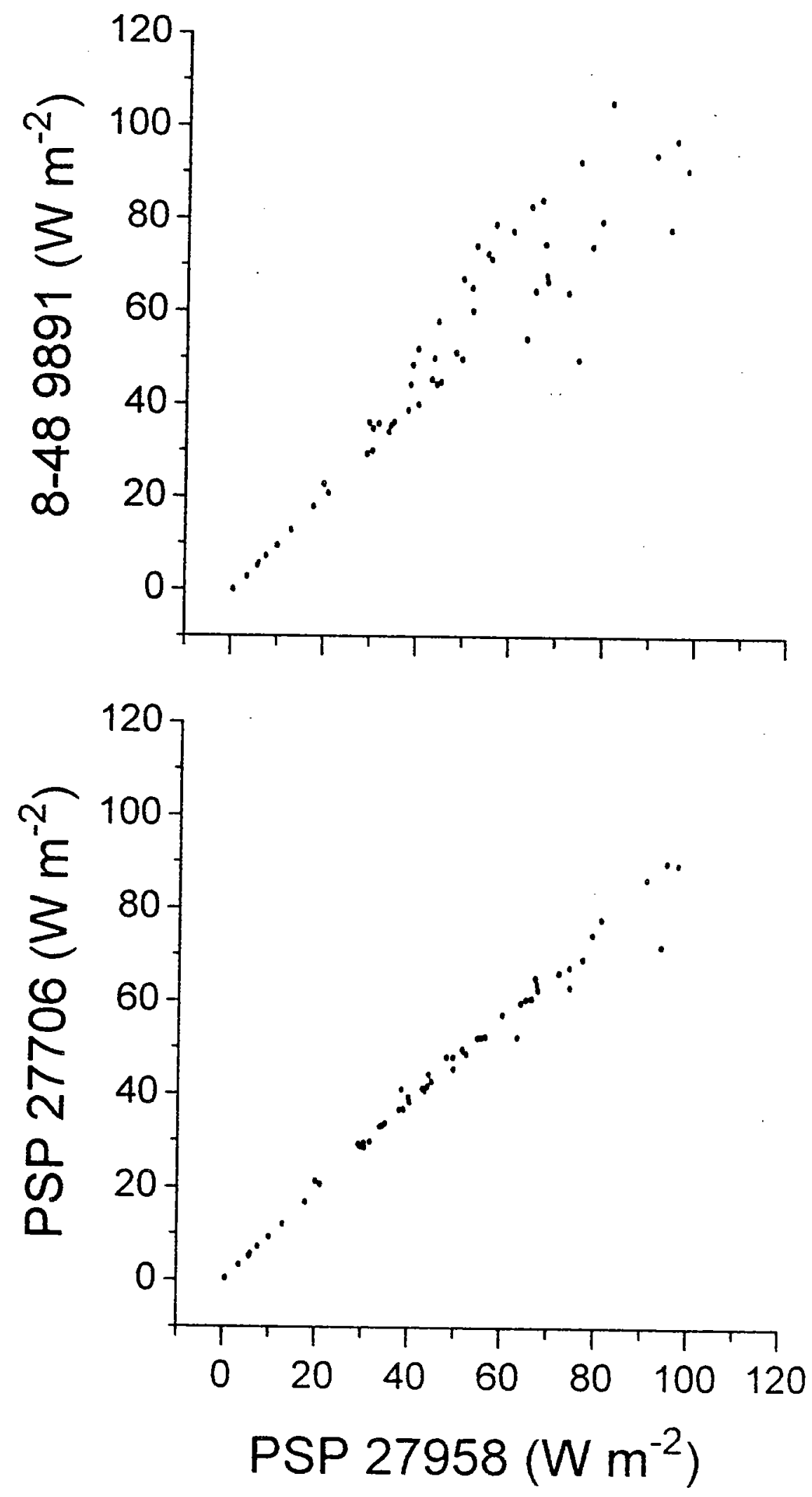

Figure $8 b$ 

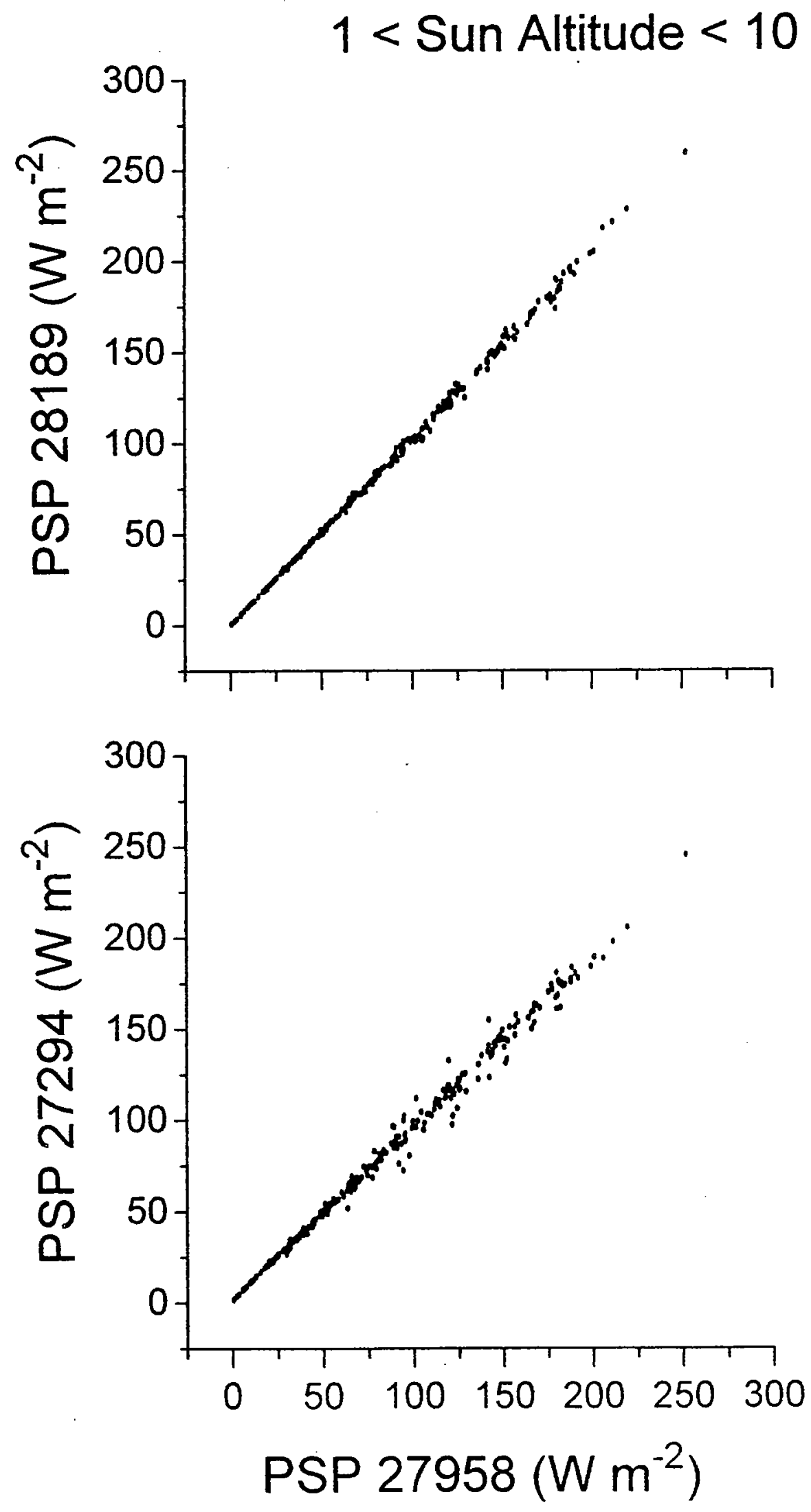

Figure 9a. $1<\theta \leq 10^{\circ}$. 
$1<$ Sun Altitude $<10$ degrees
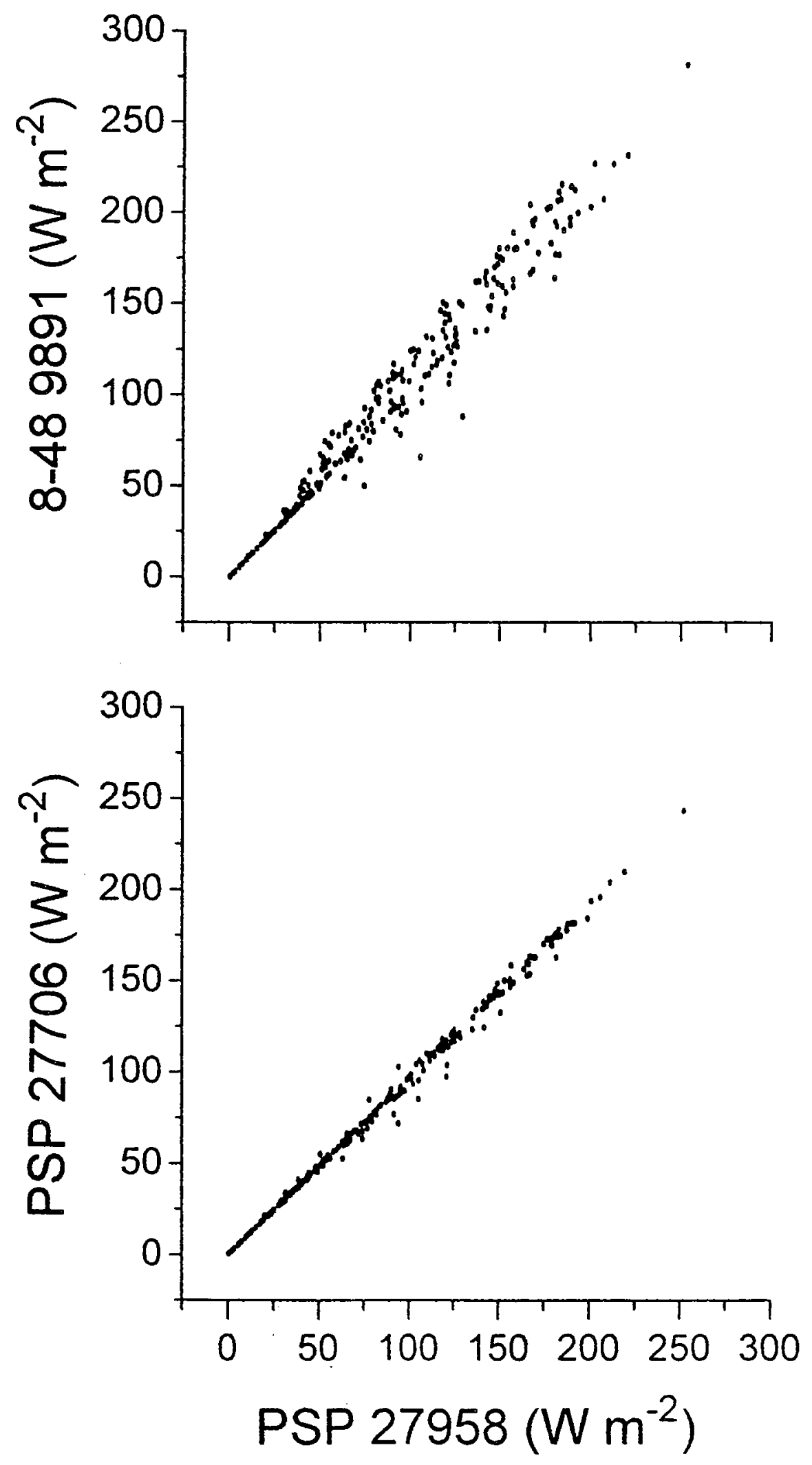

Figure $9 b$ 


\section{$10<$ Sun Altitude $<20$ deg}
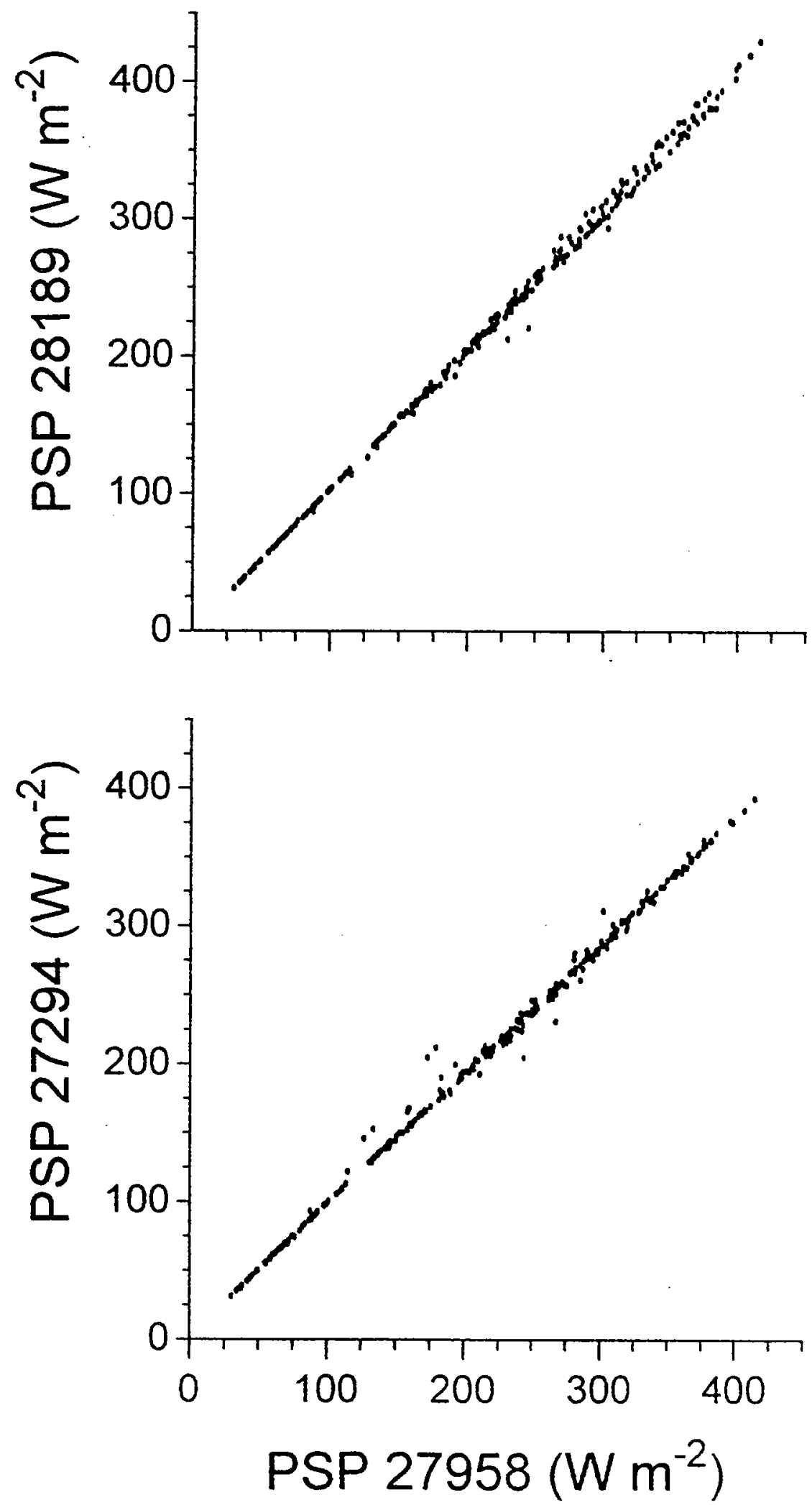

Figure 10a. $10<\theta \leq 20^{\circ}$. 
$10<$ Sun Altitude $<20 \mathrm{deg}$
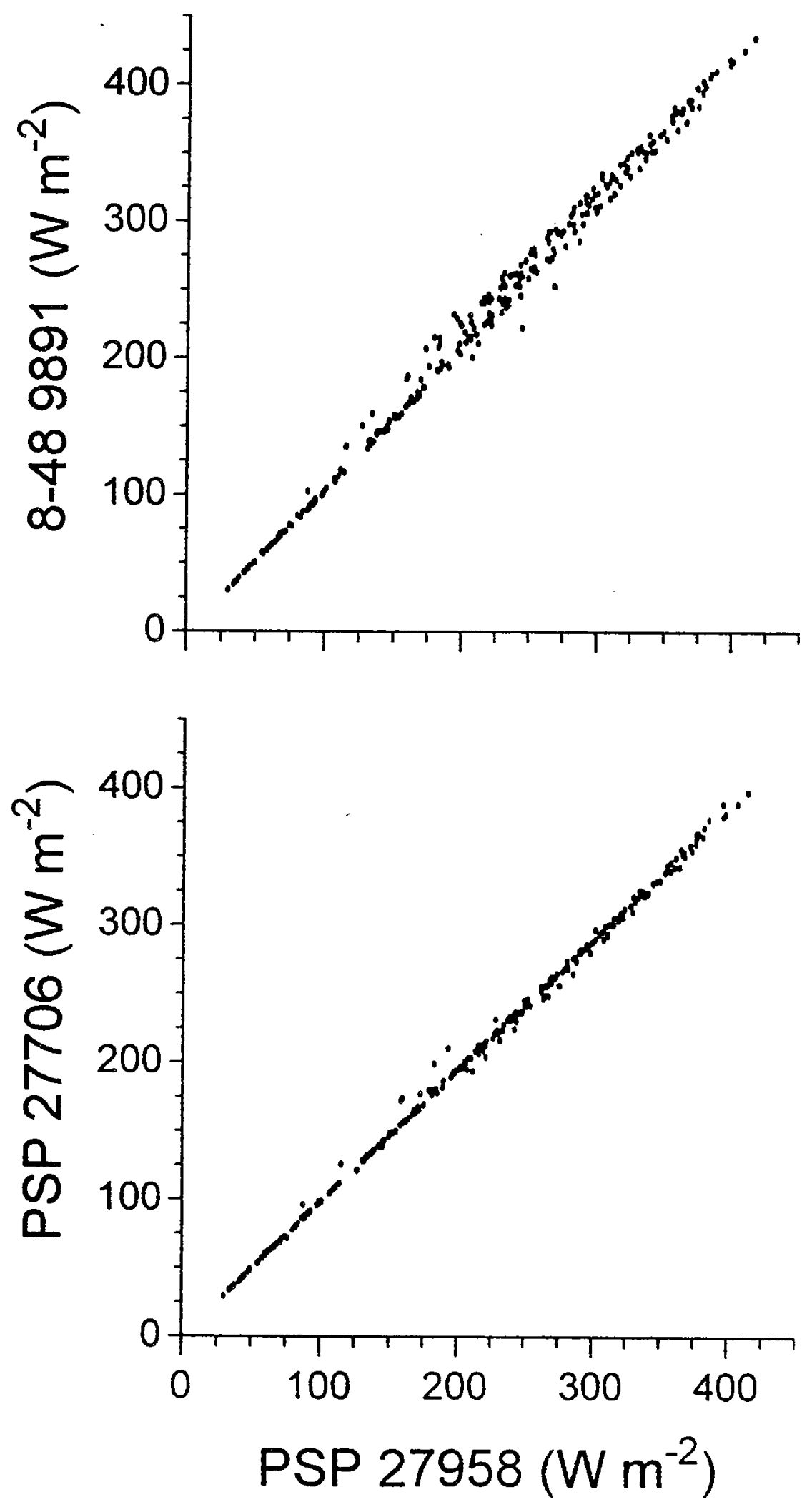

Figure 10b 

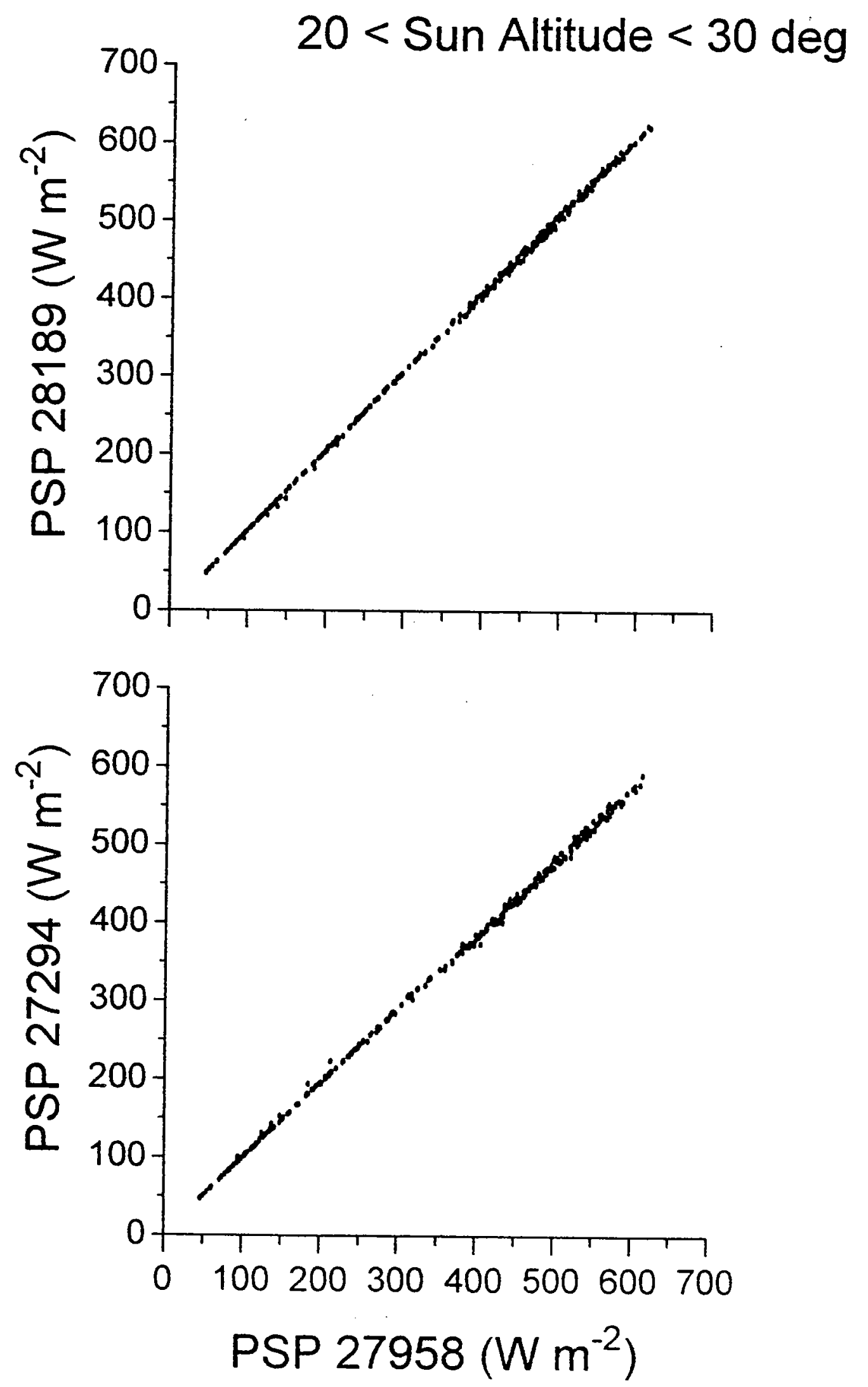

Figure 11a. $20<\theta \leq 30^{\circ}$. 

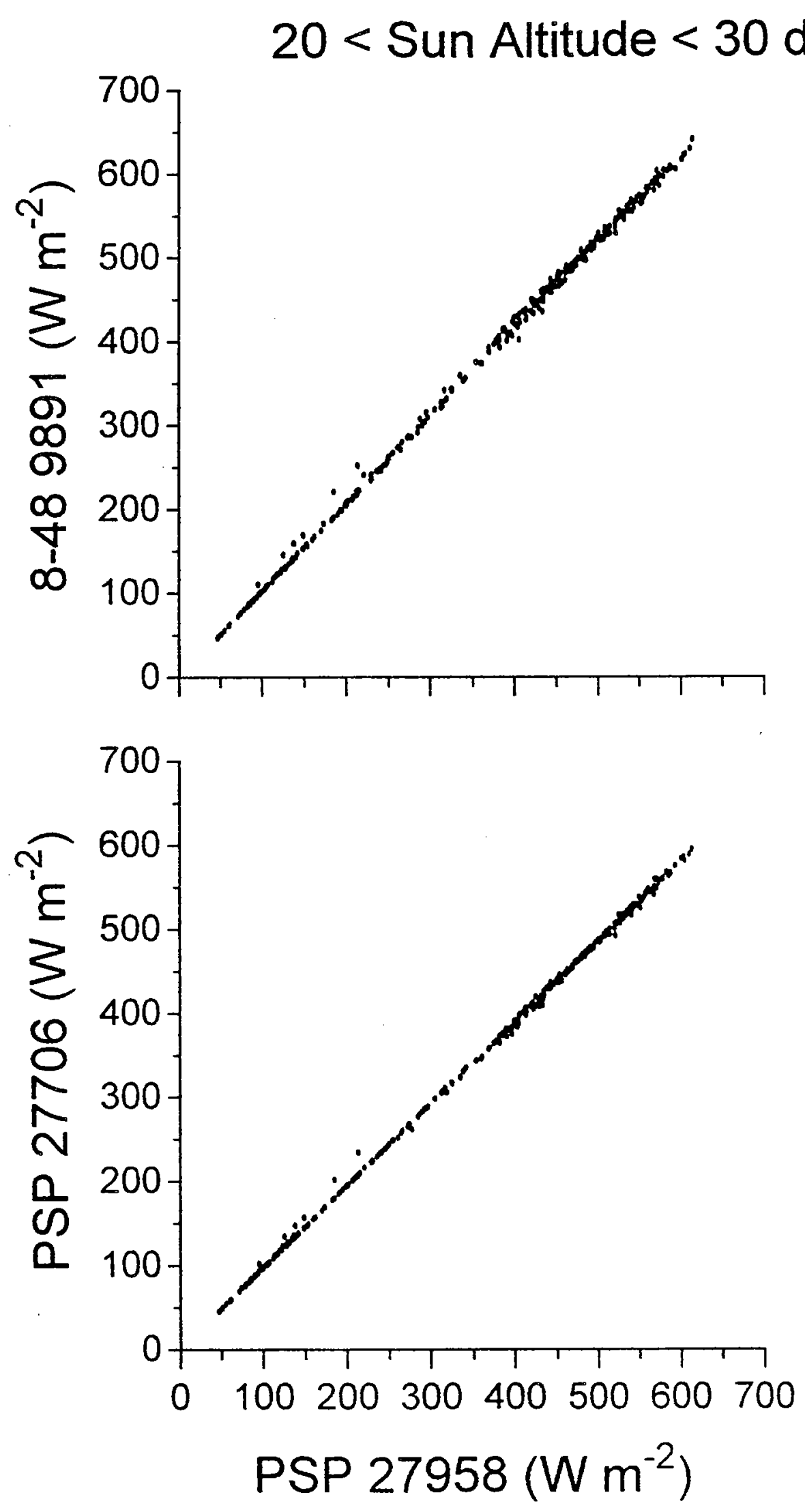

Figure 11b 


\section{$30<$ Sun Altitude $<40$ deg}
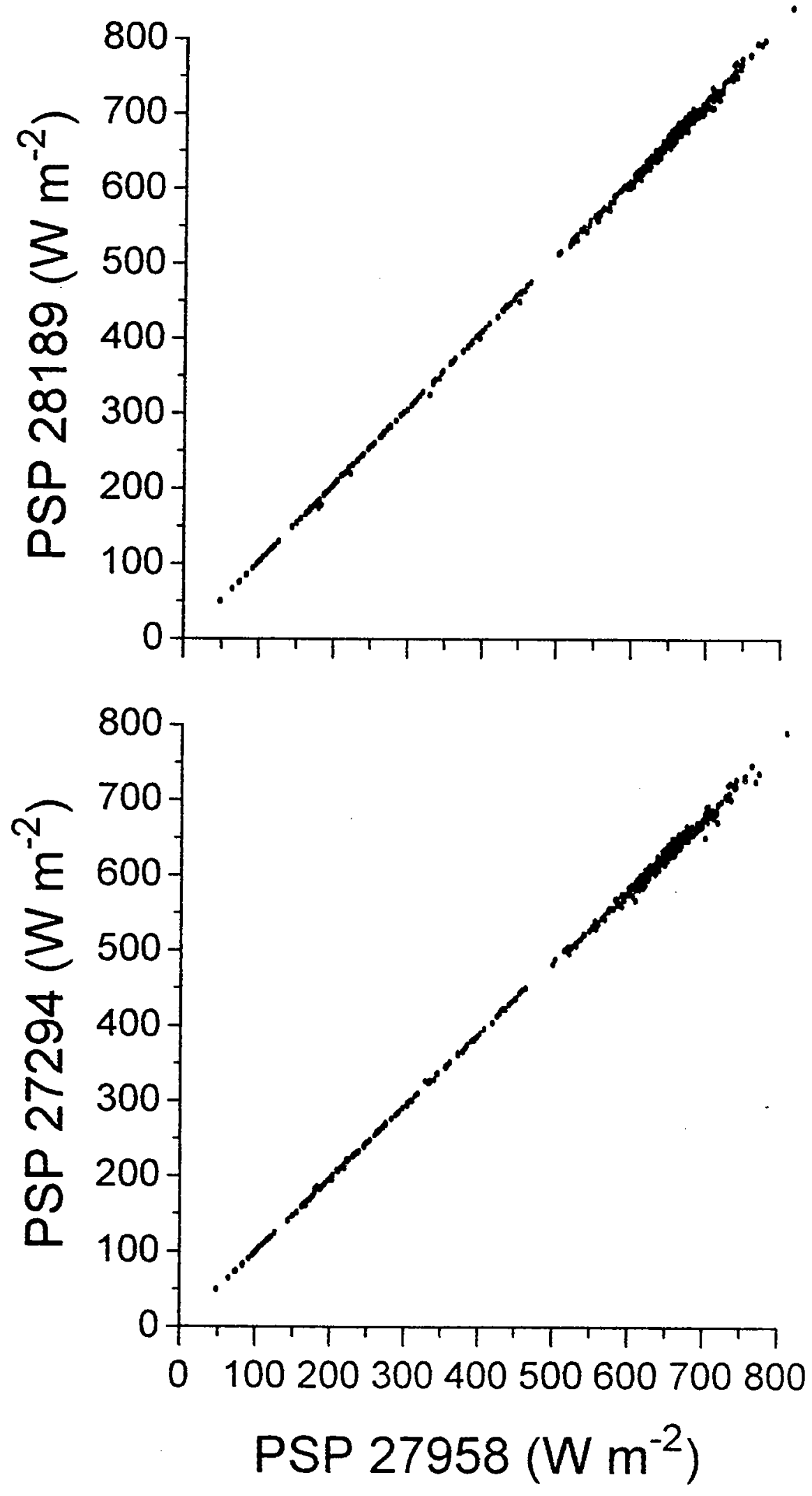

Figure 12a. $30<\theta \leq 40^{\circ}$. 

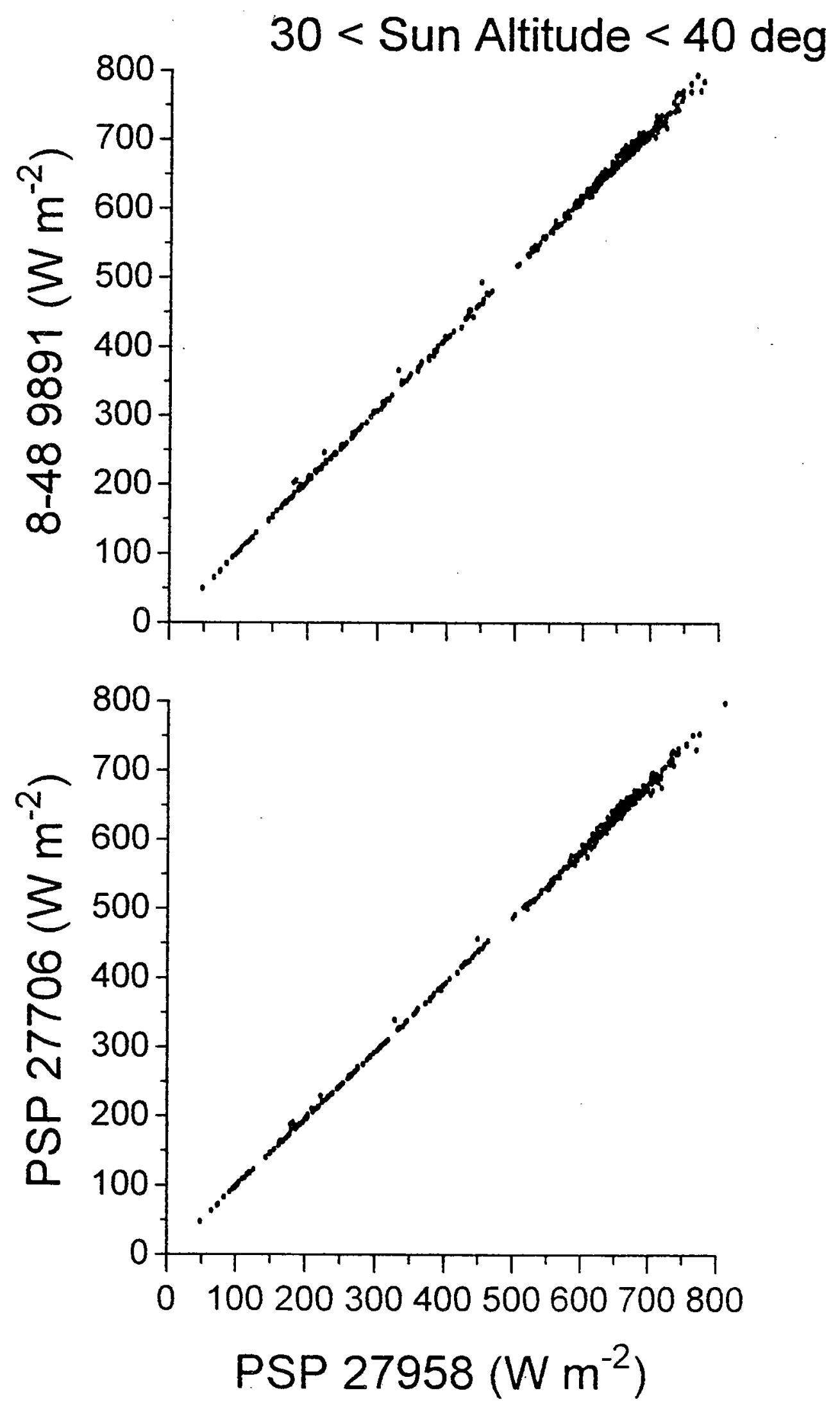

Figure 12b 

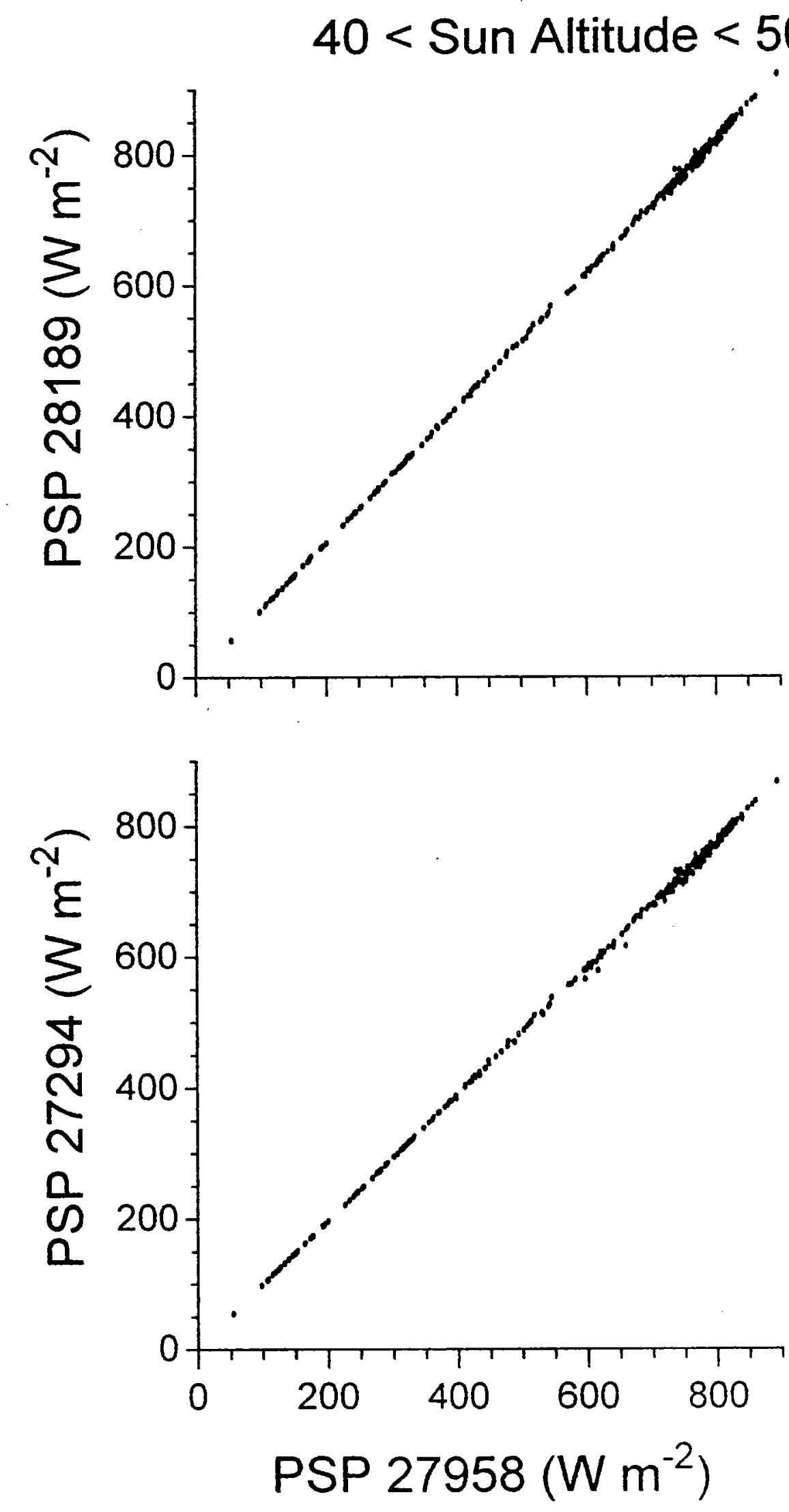

Figure 13a. $40<\theta \leq 50^{\circ}$. 

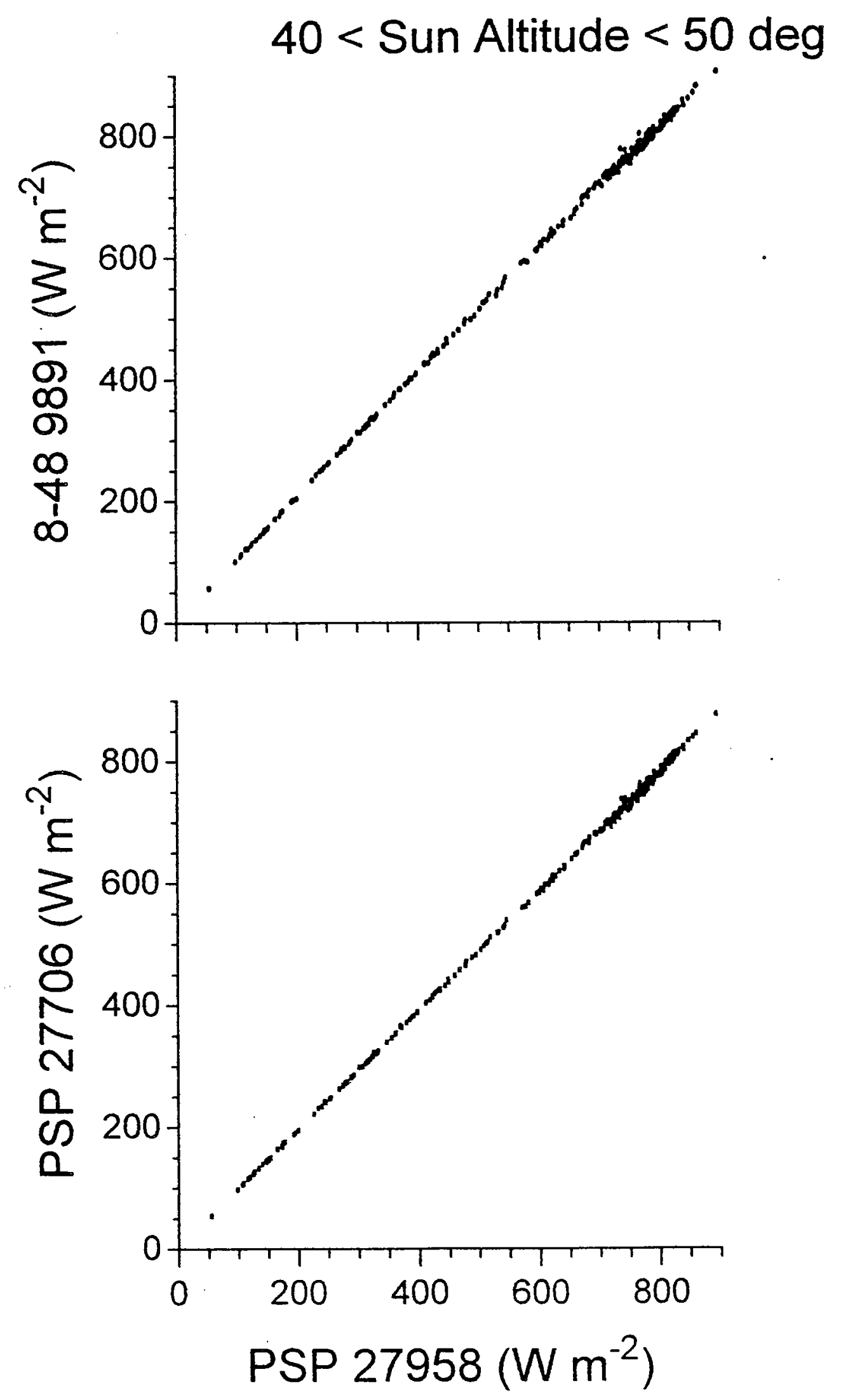

Figure 13b 

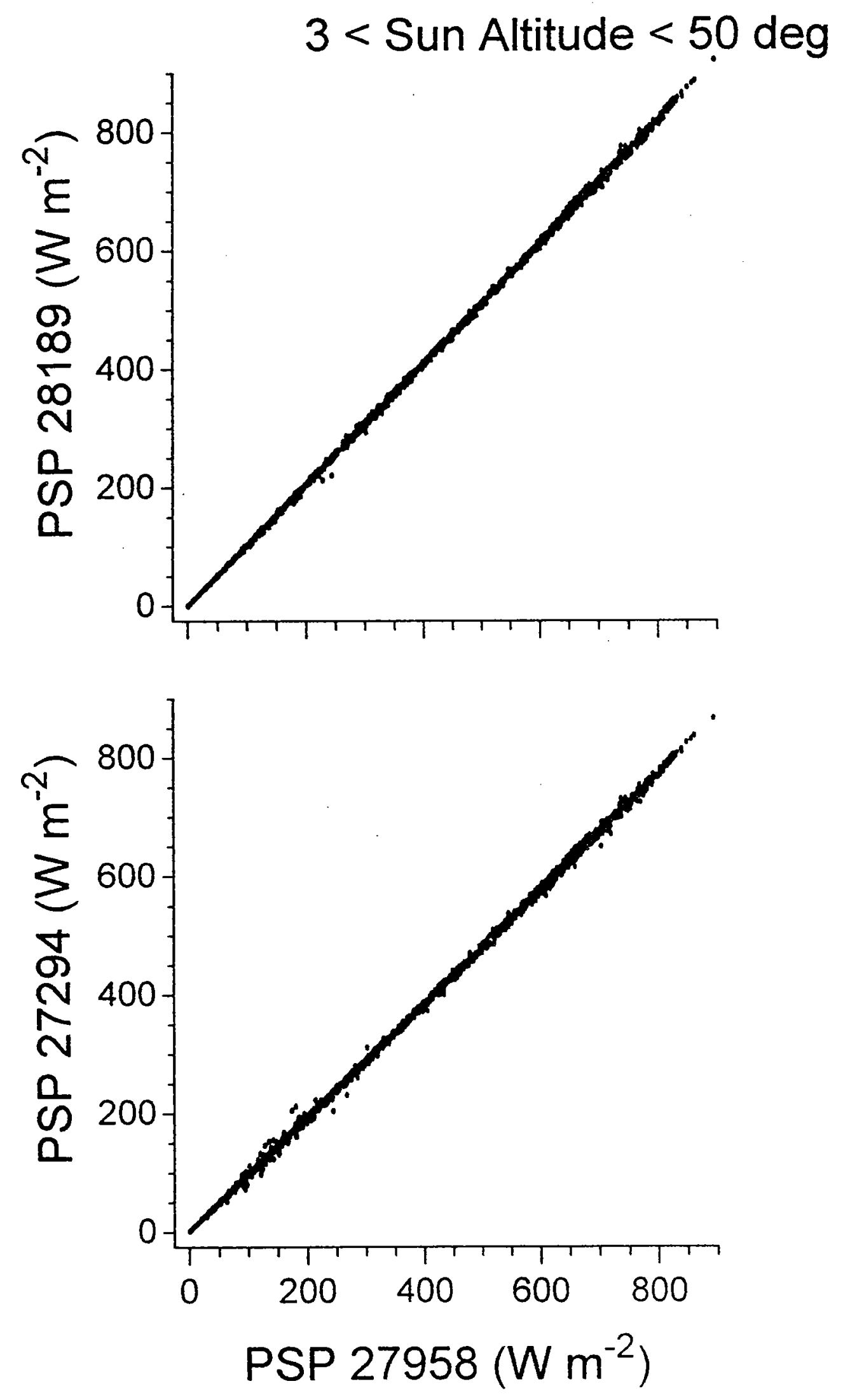

Figure 14a. $3<\theta \leq 50^{\circ}$. 
$3<$ Sun Altitude $<50 \mathrm{deg}$
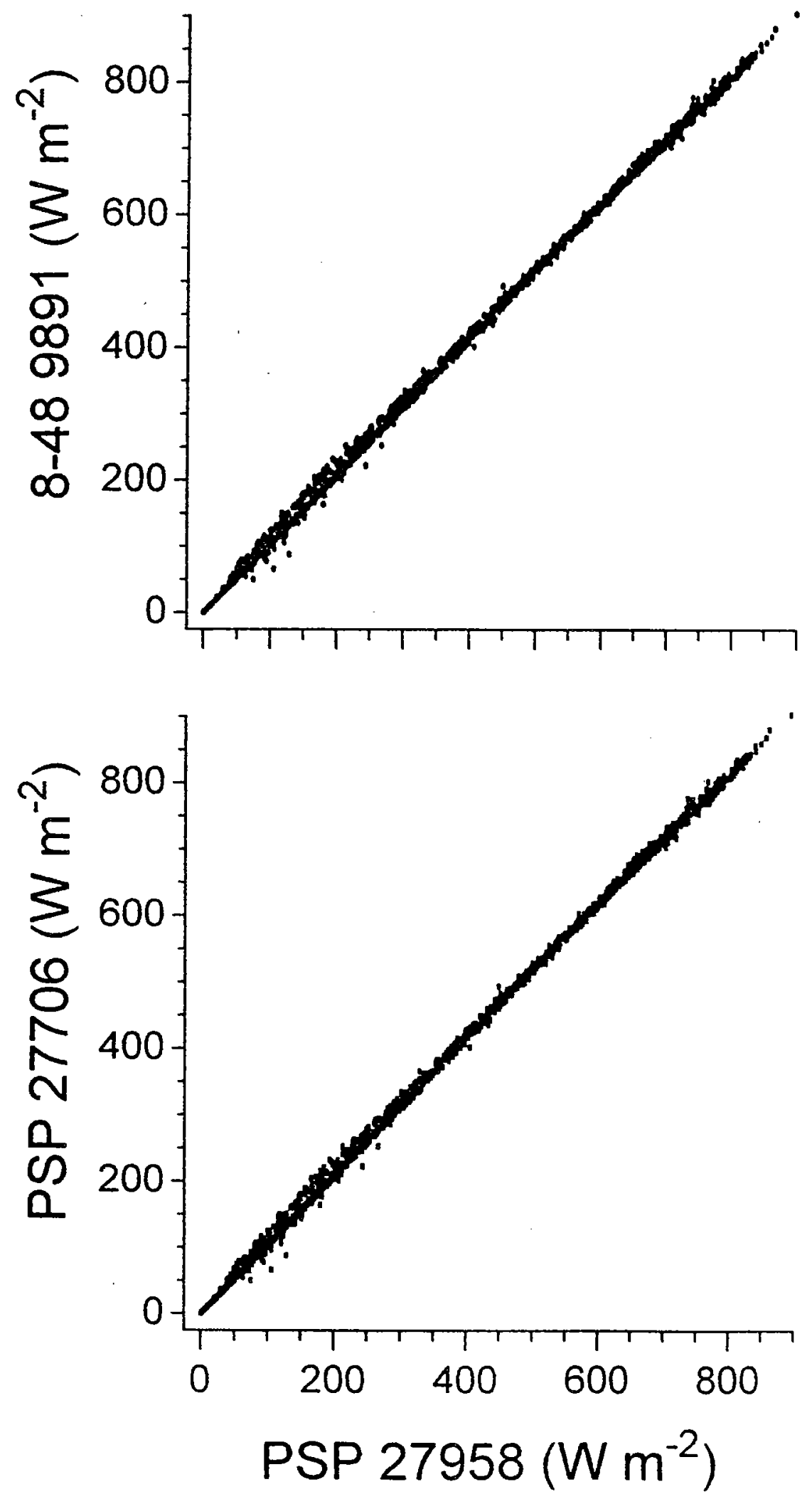

Figure 14b 


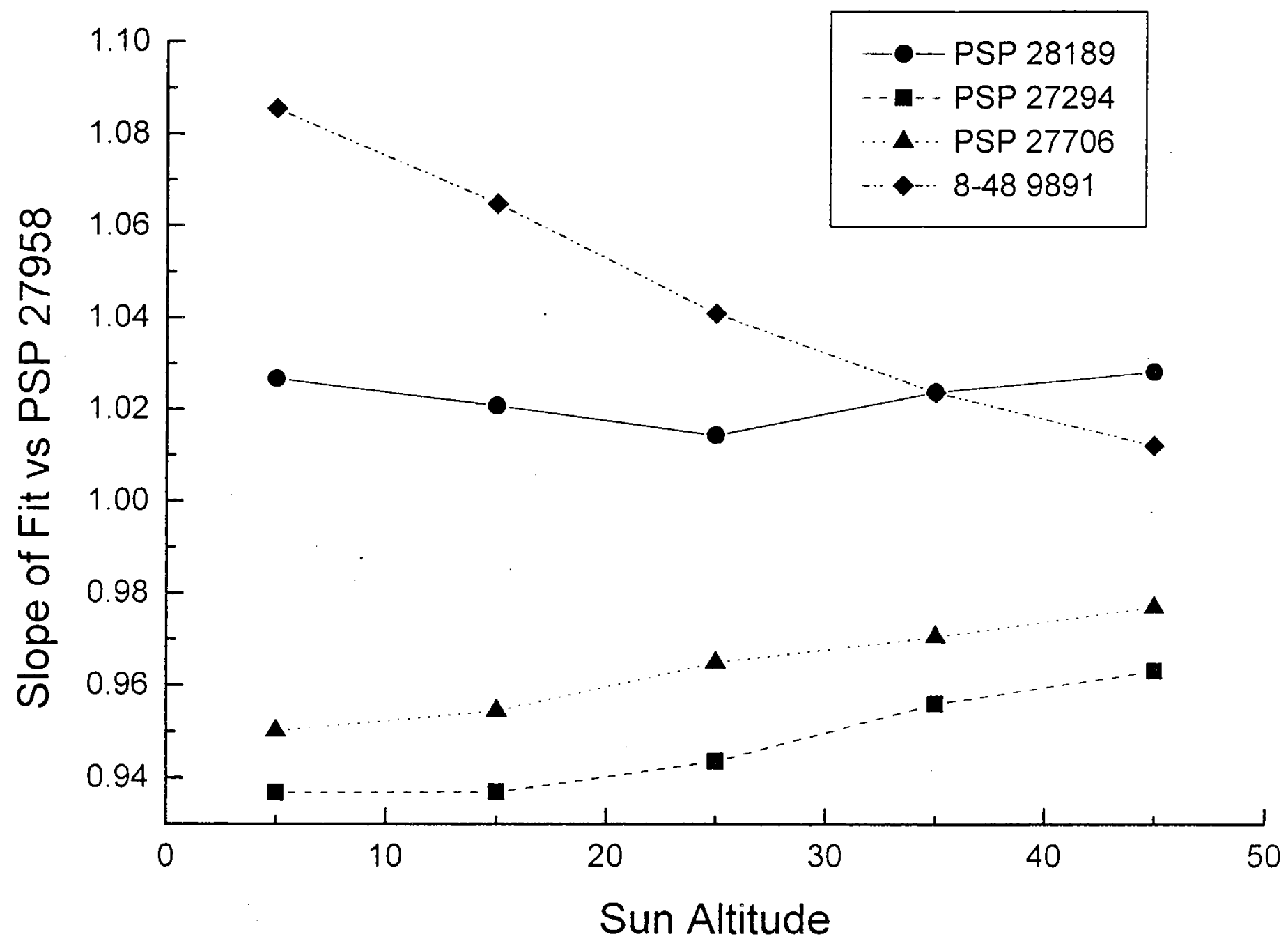

Figure 15. Slopes of linear fits of 4 PSPs $v s$ PSP 27958 as a function of sun altitude. 


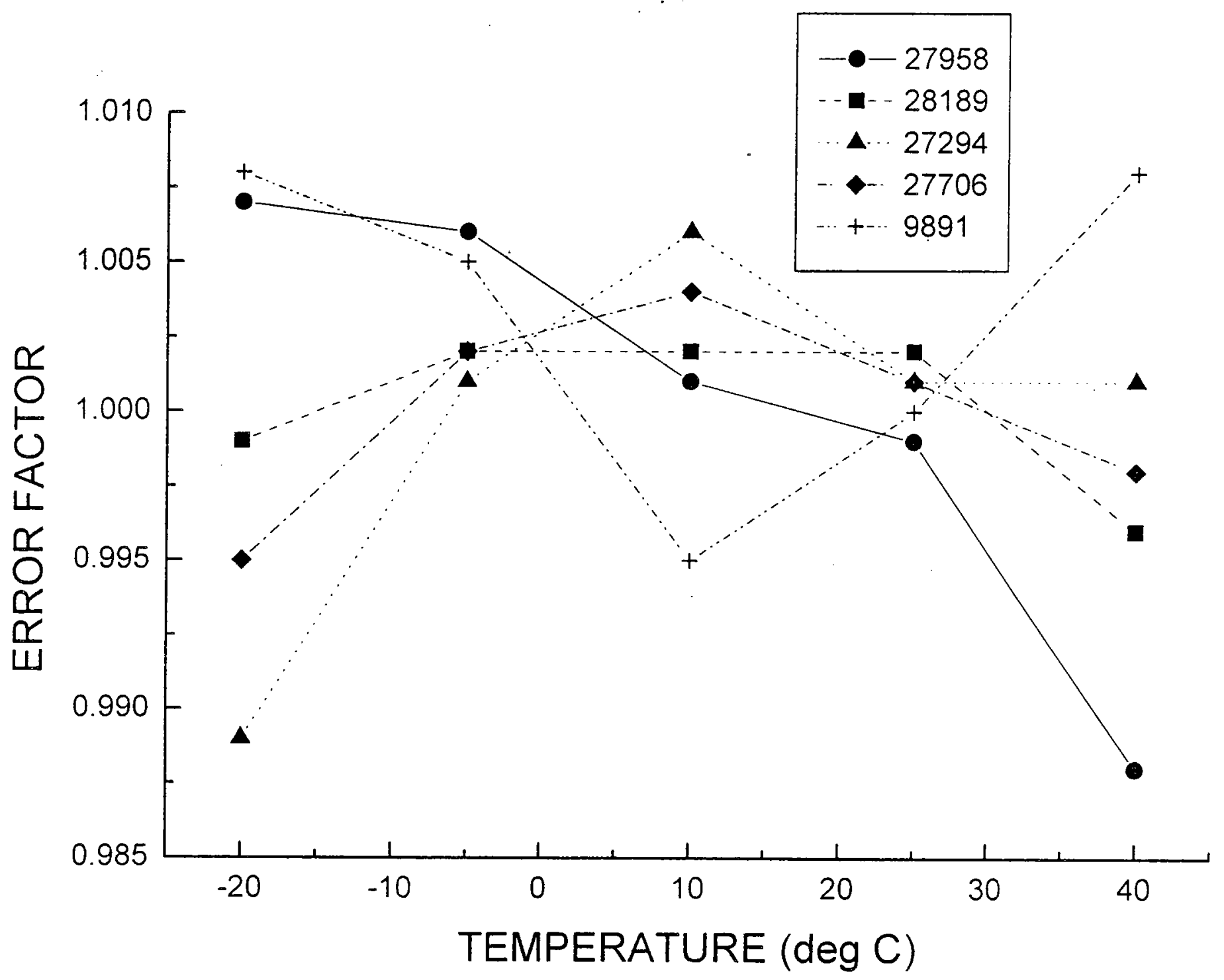

Figure 16. Temperature dependence of calibration coefficient 


\section{DOCUMENT LIBRARY}

Distribution List for Technical Report Exchange - July 1, 1993

SIO Library (serials) 0175C

Scripps Institution of Oceanography

9500 Gilman Drive

La Jolla, CA 92093-0175

Hancock Library of Biology \& Oceanography

Alan Hancock Laboratory

University of Southern California

University Park

Los Angeles, CA 90089-0371

Gifts \& Exchanges

Library

Bedford Institute of Oceanography

P.O. Box 1006

Dartmouth, NS, B2Y 4A2, CANADA

Commander

International Ic e Patrol

1082 Shennecossett Road

Groton, CT 06340-6095

NOAA/EDIS Miami Library Center

4301 Rickenbacker Causeway

Miami, FL 33149

Library

Skidaway Institute of Oceanography

10 Ocean Science Circle

Savannah, GA 31411

Institute of Geophysics

University of Hawaii

Library Room 252

2525 Correa Road

Honolulu, HI 96822

Marine Resources Information Center

Building E38-320

MIT

Cambridge, MA 02139

Library

Lamont-Doherty Geological Observatory

Columbia University

Palisades, NY 10964

Library

Serials Department

Oregon State University

Corvallis, OR 97331

Pell Marine Science Library

University of Rhode Island

Narragansett Bay Campus

Narragansett, RI 02882
Working Collection

Texas A\&M University

Dept. of Oceanography

College Station, TX 77843

Fisheries-Oceanography Library 151 Oceanography Teaching Bldg.

University of Washington

Seattle, WA 98195

Library

R.S.M.A.S.

University of Miami

4600 Rickenbacker Causeway

Miami, FL 33149

Maury Oceanographic Library

Naval Oceanographic Office

Building 1003 South

1002 Balch Blvd.

Stennis Space Center, MS, 39522-5001

Library

Institute of Ocean Sciences

P.O. Box 6000

Sidney, B.C. V8L 4B2

CANADA

Library

Institute of Oceanographic Sciences

Deacon Laboratory

Wormley, Godalming

Surrey GU8 5UB

UNITED KINGDOM

The Librarian

CSIRO Marine Laboratories

G.P.O. Box 1538

Hobart, Tasmania

AUSTRALIA 7001

Library

Proudman Oceanographic Laboratory

Bidston Observatory

Birkenhead

Merseyside L43 7 RA

UNITED KINGDOM

IFREMER

Centre de Brest

Service Documentation - Publications

BP 7029280 PLOUZANE

FRANCE 


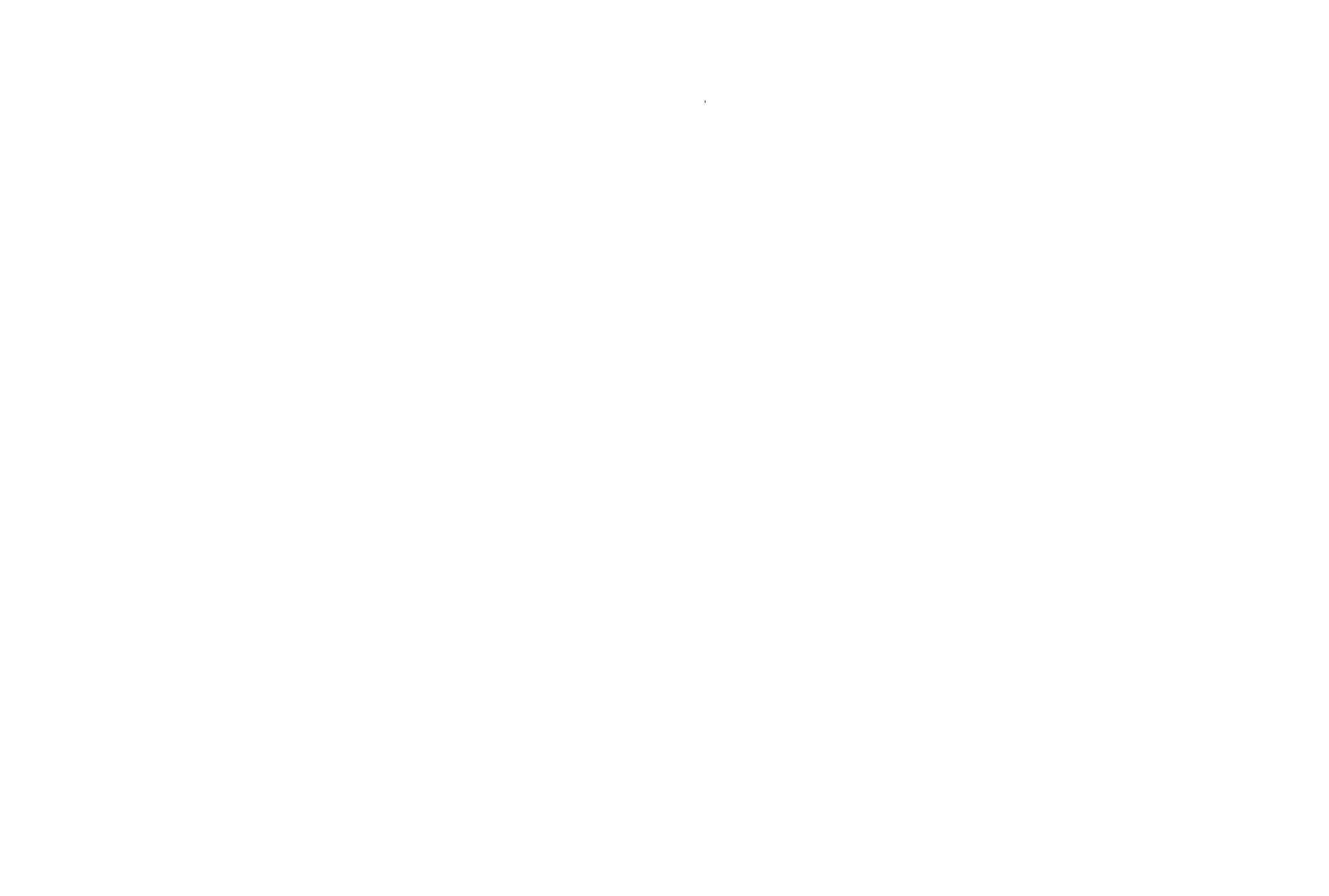




\begin{tabular}{|c|c|c|c|}
\hline $\begin{array}{l}\text { REPORT DOCUMENTATION } \\
\text { PAGE }\end{array}$ & $\begin{array}{l}\text { 1. REPORT NO. } \text { WHOI-94-30 } \\
\text { WH }\end{array}$ & 2 UOP Report 94-5 & 3. Recipient's Accession No. \\
\hline \multirow{2}{*}{\multicolumn{3}{|c|}{$\begin{array}{l}\text { 4. Title and Subtitle } \\
\text { Design and Validation of a Modified Eppley PSP Pyranometer }\end{array}$}} & $\begin{array}{l}\text { 5. Report Date } \\
\text { November } 1994\end{array}$ \\
\hline & & & 6 \\
\hline \multicolumn{3}{|l|}{ 7. Author(s) $\quad$ Richard E. Payne } & $\begin{array}{l}\text { 8. Performing Organization Rept. No. } \\
\text { WHOI-94-30 }\end{array}$ \\
\hline \multirow{2}{*}{\multicolumn{3}{|c|}{$\begin{array}{l}\text { 9. Performing Organization Name and Address } \\
\text { Woods Hole Oceanographic Institution } \\
\text { Woods Hole, Massachusetts } 02543\end{array}$}} & 10. Project/Task/Work Unit No. \\
\hline & & & $\begin{array}{l}\text { 11. Contract(C) or Grant(G) No. } \\
\text { (C) OCE-91-15000 } \\
\text { (G) }\end{array}$ \\
\hline \multirow{2}{*}{\multicolumn{3}{|c|}{$\begin{array}{l}\text { 12. Sponsoring Organization Name and Address } \\
\text { National Science Foundation }\end{array}$}} & $\begin{array}{l}\text { 13. Type of Report \& Period Covered } \\
\text { Technical Report }\end{array}$ \\
\hline & & & 14. \\
\hline
\end{tabular}

15. Supplementary Notes

This report should be cited as: Woods Hole Oceanog. Inst. Tech. Rept., WHOI-94-30.

16. Abstract (Limit: 200 words)

A modified version of the Eppley PSP pyranometer has been designed for use on ships and moored buoys. Seventeen have been built by the Eppley Laboratory for the Upper Ocean Processes Group and deployed on buoys in the deep ocean. Six others have been incorporated into IMET systems mounted on U.S. research ships. A comparison study between four Improved METeorology (IMET) PSPs and one standard PSP shows that the two are completely equivalent in performance. The IMET PSP is more corrosion resistant, compact, robust, and is easier to mate to electronics modules. It is available from the Eppley Laboratory for about the same price as the standard PSP.

17. Document Analysis a. Descriptors

pyranometer

Eppley PSP

Buoy

b. Identifiers/Open-Ended Terms

c. COSATI Field/Group

18. Availability Statement

Approved for public release; distribution unlimited.

\begin{tabular}{|l|l|}
\hline $\begin{array}{c}\text { 19. Security Class (This Report) } \\
\text { UNCLASSIFIED }\end{array}$ & $\begin{array}{c}\text { 21. No. of Pages } \\
40\end{array}$ \\
\hline 20. Security Class (This Page) & 22. Price \\
\hline & $\begin{array}{l}\text { OPTIONAL FORM 272 (4-77) } \\
\text { (Formerly NTIS-35) } \\
\text { Department of Commerce }\end{array}$ \\
\hline
\end{tabular}


